Illinois State University

ISU ReD: Research and eData

Theses and Dissertations

$1-20-2021$

\title{
Evaluating the Trauma-Informed Program for Promoting Success
}

Jessica Foley

Illinois State University, foleyjessica15@gmail.com

Follow this and additional works at: https://ir.library.illinoisstate.edu/etd

\section{Recommended Citation}

Foley, Jessica, "Evaluating the Trauma-Informed Program for Promoting Success" (2021). Theses and Dissertations. 1434.

https://ir.library.illinoisstate.edu/etd/1434

This Dissertation is brought to you for free and open access by ISU ReD: Research and eData. It has been accepted for inclusion in Theses and Dissertations by an authorized administrator of ISU ReD: Research and eData. For more information, please contact ISUReD@ilstu.edu. 


\section{EVALUATING THE TRAUMA-INFORMED PROGRAM FOR PROMOTING SUCCESS}

\section{JESSICA L. FOLEY}

78 Pages

Research has shown trauma-informed care in schools is effective in reducing the impact of trauma on children, as well as bolstering future success in those who are at-risk for experiencing trauma. Improving students school climate, emotion regulation strategies, learning behaviors, and friendships in middle school students is effective in preventing the impact of trauma. There is limited research to address implementation of trauma-informed, group-based services in middle schools. In this study, a group-based intervention targeted towards middle school students who are at-risk for trauma will be examined. 54 middle school students in grades 6-8 will be participating in the Trauma-Informed Program for Promoting Success. The students will be identified for the group through a Post-Traumatic Stress Disorder Symptoms Scale. The students in this study will take pre and post-test surveys measuring their perception of school climate, emotion regulation, learning behaviors, and friendships. Their discipline record and academic performance will also be measured at pre- and post-intervention through a record review. A correlational matrix will be used to determine if demographic variables correlate with study variables. If so, they will be entered as covariates. Data was analyzed using a repeated measures ANCOVA, examining between, within, and between-within interactions. The analysis measured a difference between the groups pre- and post-test measures.

KEYWORDS: trauma; trauma-informed care; group-based services; school climate; emotion regulation; learning behaviors; friendships 
EVALUATING THE TRAUMA-INFORMED PROGRAM FOR PROMOTING SUCCESS

JESSICA L. FOLEY

A Dissertation Submitted in Partial

Fulfillment of the Requirements

for the Degree of

DOCTOR OF PHILOSOPHY

Department of Psychology

ILLINOIS STATE UNIVERSITY

2021 
(C) 2021 Jessica L. Foley 
EVALUATING THE TRAUMA-INFORMED PROGRAM FOR PROMOTING SUCCESS

JESSICA L. FOLEY

COMMITTEE MEMBERS:

Adena Meyers, Chair

Leandra Parris

Karen Stipp

Kyle Miller 


\section{ACKNOWLEDGMENTS}

I would first like to thank Adena Meyers for her endless support and encouragement on this project. Thank you for all of the time, effort, and mentorship you have provided me over the last few years. I would also like to thank Leandra Parris for her support through the development of this research idea. Thank you for the endless positive encouragement. Further, I greatly appreciate my committee members Karen Stipp and Kyle Miller for their guidance and support on this project.

To my cohort, I really could not have done this without you each and every one of you. Stephanie Aubuchon, thank you for being there with me through it all. Your kindness, humor, selflessness and generosity has truly helped me along this journey. I would not have survived all of the late nights and long hours without your daily support and encouragement.

I am extremely grateful for you, Henry. Your endless dedication and support of my goals has not gone unnoticed. Thanks for always being there, forever and always. Grandma and Grandpa, you will forever be my greatest cheerleaders. The daily phone calls with you, Grandpa, always made my day. You are now the best guardian angel I could ask for. Tommy, your sense of humor and your ability to light up a room has put a smile on my face when times were tough, thank you. Above all, I would like to thank my parents for their endless love and support, and their dedication to my personal and professional growth and development. I would not be here today without you both. Thank you for teaching me how to live life to the fullest, and to appreciate every moment. I love you, Mom and Dad. 


\section{CONTENTS}

Page

ACKNOWLEDGMENTS

$\begin{array}{ll}\text { CONTENTS } & \text { ii }\end{array}$

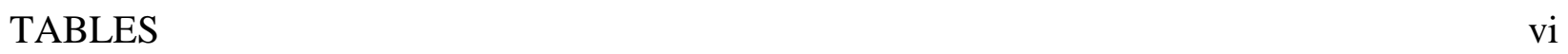

FIGURES

CHAPTER 1: INTRODUCTION 1

CHAPTER II: LITERATURE REVIEW

$\begin{array}{ll}\text { Trauma Defined } & 4\end{array}$

$\begin{array}{ll}\text { Trauma-Informed Care } & 7\end{array}$

$\begin{array}{ll}\text { Four key assumptions } & 8\end{array}$

Principles of Trauma-Informed Care $\quad 9$

$\begin{array}{ll}\text { Safety } & 9\end{array}$

$\begin{array}{ll}\text { Trustworthiness and Transparency } & 10\end{array}$

$\begin{array}{ll}\text { Peer Support } & 10\end{array}$

$\begin{array}{ll}\text { Collaboration and mutuality } & 11\end{array}$

Empowerment, voice, and choice 11

$\begin{array}{lr}\text { Cultural, historical, and gender issues } & 12\end{array}$

Trauma-Informed Approach in Schools $\quad 12$

$\begin{array}{ll}\text { Group Based Services and Tiered Systems of Intervention } & 17\end{array}$

Response to Intervention $\quad 17$

$\begin{array}{ll}\text { Social Emotional Learning } & 17\end{array}$

$\begin{array}{ll}\text { TIPPS: An overview } & 19\end{array}$ 
Development

Implementation of the Six Principles of Trauma Informed Care

Implementation of the Ten Essential Elements of a Trauma-Informed School System 22

The Four Components

Research Questions and Hypotheses

Research Question 1

Hypothesis 1

Research Question 2

Hypothesis 2

Research Question 3

Hypothesis 3

Research Question 4

Hypothesis 4

Research Question 5

Hypothesis 5

Research Question 6

Hypothesis 6

Research Question 7

Hypothesis 7

Participants

Measures 
School Climate

Emotion Regulation

Learning Behaviors

Friendships

Record Review

Procedure

Measures of Internal Consistency

Group Differences Analysis

Demographic Differences

Pre-test Differences

Analyses of Covariances

Post Traumatic Stress Disorder Symptoms Scale

Emotion Regulation

Conflict Management

School Climate

Learning Behaviors

Measures of Academic Progress

Analysis of Behavioral Referrals

Interpretation of Findings

Hypothesis one 
$\begin{array}{ll}\text { Hypothesis two } & 47\end{array}$

$\begin{array}{ll}\text { Hypothesis three } & 48\end{array}$

$\begin{array}{ll}\text { Hypothesis four } & 48\end{array}$

Hypothesis five $\quad 49$

$\begin{array}{ll}\text { Hypothesis six } & 49\end{array}$

$\begin{array}{ll}\text { Hypothesis seven } & 49\end{array}$

$\begin{array}{ll}\text { Strengths and Limitations } & 50\end{array}$

$\begin{array}{ll}\text { Strengths } & 50\end{array}$

$\begin{array}{ll}\text { Limitations } & 51\end{array}$

$\begin{array}{ll}\text { Future Directions } & 53\end{array}$

$\begin{array}{ll}\text { Research } & 53\end{array}$

$\begin{array}{ll}\text { Practice } & 56\end{array}$

$\begin{array}{ll}\text { REFERENCES } & 58\end{array}$

$\begin{array}{ll}\text { APPENDIX A: SCREENER } & 67\end{array}$

APPENDIX B: SCHOOL CLIMATE SCALE $\quad 69$

APPENDIX C: EMOTION REGULATION SCALE

APPENDIX D: LEARNING BEHAVIORS SCALE 76

$\begin{array}{ll}\text { APPENDIX E: FRIENDSHIP SCALE } & 78\end{array}$ 


\section{TABLES}

Table

Page

1. Development and Implementation of Trauma-Informed Care in Schools (SAMHSA, 2014)

2. TIPPS Curriculum

3. Fall and Winter Cronbach Alphas for Subscales of the Emotion

Regulation Questionnaire, Conflict Management Questionnaire, Department of Education School Climate Scale, Learning Behaviors Scale, and Child Post Traumatic Stress Disorder Symptoms Scale

4. Chi-Square Tests Examining Demographic Differences of Experimental Group and Control Group

5. Differences Between the Emotion Regulation Questionnaire, Conflict Management Questionnaire, Department of Education School Climate Scale, Learning Behaviors Scale, and Child Post Traumatic Stress Disorder Symptoms Scale According to Group at Fall

6. Percentage of Missing Data Substituted using Mean Substitution

7. ANCOVA Comparing Participant's Responses on the Emotion Regulation Questionnaire, Conflict Management Questionnaire, Department of Education School Climate Scale, Learning Behaviors Scale, the Child Post Traumatic Stress Disorder Symptoms Scale, English MAP Scores, and Math MAP Scores According to Group 


\section{FIGURES}

Figure

Page

1. Full model of Trauma-Informed Care, Including Four Key

Assumptions and Six Principles that are Integrated Throughout the Process of Service Delivery (SAMHSA, 2014)

2. Projected Development of TIPPS using the PCSIM Framework

3. Procedures

4. Treatment Group Behavior Referrals

5. Control Group Behavior Referrals 


\section{CHAPTER 1: INTRODUCTION}

Research states that more than two-thirds of children report at least one traumatic experience by age 16 (SAMHSA, 2020). Trauma results from one or multiple negative events, or long-term exposure to a negative experience, that threatens the physical, mental, and/or emotional condition of an individual. The experience of a traumatic event, or events, could have a lasting impact on the person's physical and mental health (Rossen \& Hull, 2013; Steele \& Malchiodi, 2011). It is important to remember that everyone responds differently to traumatic events.

In order to target the negative impacts of trauma, Trauma-Informed Care (TIC) is crucial to intervention effectiveness. To follow a trauma informed approach the four key assumptions of TIC and the six principles of TIC should be followed. The four assumptions are to recognize, realize, respond, and resist revictimization (SAMHSA, 2014). Therefore, it is assumed that a TIC approach would follow these assumptions. By following these assumptions individuals who work with children who have experienced trauma can help to bolster their future development of emotional, academic, and behavioral skills that will contribute to future successes. In combination with the four key assumptions to a trauma informed approach, there are six key principles to guide the implementation of a trauma informed approach. The six key principles of TIC are safety, trustworthiness and transparency, peer support, collaboration and mutuality, empowerment, voice, and choice, and cultural, historical, and gender issues (SAMHSA, 2014).

The implementation of a trauma-informed approach in schools is important because to support student's academic achievement all students must feel safe and supported in their environment (NCTSN, 2020). The National Child Traumatic Stress Network (NCTSN) identified ten Essential Elements of a Trauma-Informed School System. These ten steps are identifying and 
assessing traumatic stress, addressing and treating traumatic stress, teaching trauma education and awareness, having partnerships with students and families, creating a trauma-informed learning environment (social/emotional skills and wellness), being culturally responsive, integrating emergency/management/crisis response, understanding and addressing staff self-care and secondary traumatic stress, evaluating and revising school discipline policies and practices, and collaborating across systems and establishing community partnerships.

The implementation of TIC in schools works to target all students who are at-risk for, or who are experiencing traumatic stress. This is specifically beneficial for students who otherwise may not receive intervention (Cavanaugh, 2016). The National Child Traumatic Stress Network (2008), reports that middle school students who have experienced trauma are likely to display many changes in behavior such as decreased attention, increased hyperactivity, a distinct change in school performance, irritability in social relationships, anger outbursts, social withdrawal, and increased absences. Further, teachers may notice an increased report of somatic complaints, repeated descriptions of the traumatic event, a sensitivity to loud sounds, physical contact, sudden actions, sleep disturbance, avoidance, and a lack of emotional expression pertaining to the event. The implementation of a trauma-informed approach in schools will provide students with the supports needed to cope with these reactions and succeed academically, socially, emotionally, and behaviorally.

To this end, the Trauma-Informed Program for Promoting Success (TIPPS) was created. TIPPS is currently in the process of being developed by following the Participatory CulturalSpecific Intervention Model (PCSIM). TIPPS is a program that is implemented within the MultiTiered System of Support. TIPPS is a Tier 2 social-emotional and behavioral intervention, that is implemented using a trauma-informed approach to help students with social-emotional and 
behavioral concerns, as well as target students who have experienced trauma or are at risk for trauma-related symptoms. TIPPS was developed using recommendations from Blitz \& Lee (2015), such as targeting school climate, discussing the body's stress response, coping strategies, conflict management, and relationships, as well as implementing clear rules and expectations and effective collaboration with school counselors. The purpose of TIPPS is to enhance the success of students who have been identified as being at-risk for, or currently experiencing traumatic stress. The program facilitates their success in school through the implementation of lessons related to school climate, emotion regulation, learning behaviors, and friendships. Specific details of this program will be provided in the next chapter. The proposed study will examine the effectiveness of TIPPS in enhancing student perception of their school climate, emotion regulation, learning behaviors, and friendships. 


\section{CHAPTER II: LITERATURE REVIEW}

The following literature review uses the trauma-informed literature to rationalize the importance of trauma-informed care (TIC) and inform the implementation of a trauma-informed approach in schools through the group-based and multi-tiered services framework. Further, an overview of the development of the Trauma-Informed Program for Promoting Success (TIPPS) is explained, including the use of the Participatory Cultural-Specific Intervention Model (PCSIM) for intervention development.

\section{Trauma Defined}

Trauma is an emotional response to an event that effects mental, physical, and/or socialemotional functioning (Substance Abuse and Mental Health Services Administration [SAMHSA], 2014; American Psychological Association [APA], 2013). Traumatic events threaten injury, death, physical integrity, and psychological safety (APA, 2013). Examples of trauma stressors may be homelessness, school and community violence, natural disasters, illness, death, child abuse/maltreatment, psychosocial dysfunction, family conflict, chronic stress, peervictimization, etc. (Rosen \& Hull, 2013; Brock et al., 2016, Viderouek, King, \& Merianos, 2016). More than two thirds of children report at least one traumatic experience by age 16 (SAMHSA, 2020). Further, 1 in 4 high school students report that they were in at least one physical fight, 1 in 5 high school students report that they are bullied at school, and 1 in 6 report that they experience cyberbullying (SAMHSA, 2020).

Children are the most vulnerable population to experience the effects of trauma (Perry, Pollard, Blakley, Baker, \& Vigilante, 1995) which can lead to development of new fears, separation anxiety, sadness, anhedonia, reduced concentration, decline in schoolwork, anger, somatic complaints, and irritability (APA, 2008). Traumatic experiences may lead to intense 
feelings of distress, shame, helplessness, and fear (Rossen and Hull, 2013). Middle school aged children who have experienced trauma are more likely to feel depressed or alone, begin abusing alcohol or drugs, and become involved in risk sexual behavior (SAMHSA, 2020).

Traumatic events may occur suddenly and be unexpected, making it difficult to cope with the event. The experience of trauma is dependent on how the individual perceives the traumatic stressor. Therefore, an experience may be traumatic to one individual, but not traumatic to another individual. This is based on the child's age, perception of the event, the strength of their support system, their ability to cope with the event, and previous life experiences (Rossen \& Hull, 2011). For example, a child with effective coping strategies may be able to manage a family member's death in a more adaptive manner than a child who does not have many coping strategies. Therefore, it is important to foster resiliency within trauma-informed systems.

Exposure to trauma can be acute or chronic. Acute stressors are those that occur in a single event, such as death of a family member, or being involved in an accident. An acute stressor is categorized as having been exposed to one threatening event with a clear beginning and end (Brock et al., 2016). Example of events that could be acute stressors are witnessing or being involved in an accident and/or violence one specific time. As the severity of the event increases, the demands placed on the child are higher and deplete their emergency and coping resources. Chronic stressors are those that occur consistently over time and can lead to complex trauma (Brock et al., 2016; Parris \& Foley, 2018). Complex trauma is when a child experiences a chronic stressor or is repeatedly exposed to the threat. Examples of chronic stressors are ongoing abuse, homelessness, and neglect. These events may threaten the child's safety for a long period of time (Terrasi \& Crain de Galarce, 2017). Over time, the demands of complex trauma can 
become overwhelming and deplete a child's emergency and coping resources, leading to deficits in regulating emotions, relationship skills, and problem-solving skills.

Consideration of whether or not a child has been exposed to trauma is important because this exposure may lead to a constant state of hyperarousal (APA, 2013; Perry et al., 1995; Streeck-Fischer \& van der Kolk, 2000; Tian, 2005; Sherin \& Nemeroff, 2011). During a period of constant hyperarousal, the fight, flight, or freeze response can be evoked even when presented with a minor stressor (Perry et al., 1995; Streeck-Fischer \& van der Kolk, 2000). Therefore, it is possible for children who have been exposed to trauma to have difficulties concentrating because they are highly focused on observing the environment around them to stay safe (Perry et al., 1995; Streeck-Fischer \& van der Kolk, 2000; Tian, 2005). This can negatively impact children's physical, social, emotional, and academic development, such as have a negative impact on executive functioning, such as inhibitory control, cognitive flexibility, and working memory. Additional impacts include disrupted concentration, language processing, and decision-making (Barr, 2018; APA, 2013). Overall, exposure to chronic trauma can lead to poor physical and cognitive health (APA, 2013; Perry et al., 1995; Streeck-Fischer \& van der Kolk, 2000).

Exposure to trauma can also lead to social and emotional difficulties (Ford, Elhai, Connor, \& Frueh, 2010; Terrasi \& Crain de Galarce, 2017). Social difficulties may involve trusting others, establishing relationships, interpreting verbal and nonverbal cues, and understanding others' viewpoints. Trauma involving a caregiver could also lead to a disruption in the development of social relationships. Children who have experienced trauma may have difficulty trusting and bonding with other peers and educators (Tishelman, Haney, Greenwald O'Brien, \& Blaustein, 2010). Emotional difficulties are those such as low emotional control, impulsive behavior, hopelessness, etc., (National Child Traumatic Stress Network, 2008). 


\section{Trauma-Informed Care}

The Trauma-Informed Care (TIC) approach is helpful because support for people who have experienced, or are at risk of experiencing, trauma can occur in non-clinical settings such as schools, community centers, detention facilities, etc. Those who are trained in TIC are able to understand the importance of establishing positive relationships with the person who has endured trauma. For example, the existence of positive adult relationships will help establish resiliency in children who are at-risk for, or have been exposed to, trauma (Benard, 2004). The implementation of this approach will help children in many settings by providing safety, building social-connections, and fostering resiliency in children who have experienced trauma (Bath, 2008). There are four key assumptions regarding TIC that are adopted by agencies or systems implementing this approach. In addition, there are six guiding principles for implementing services and providing mental health services to individuals experiencing the impact of trauma. These key assumptions and principles will be discussed in the next section. For an understanding of the integration of the four key assumption and the six principles to create TIC, see Figure 1. 


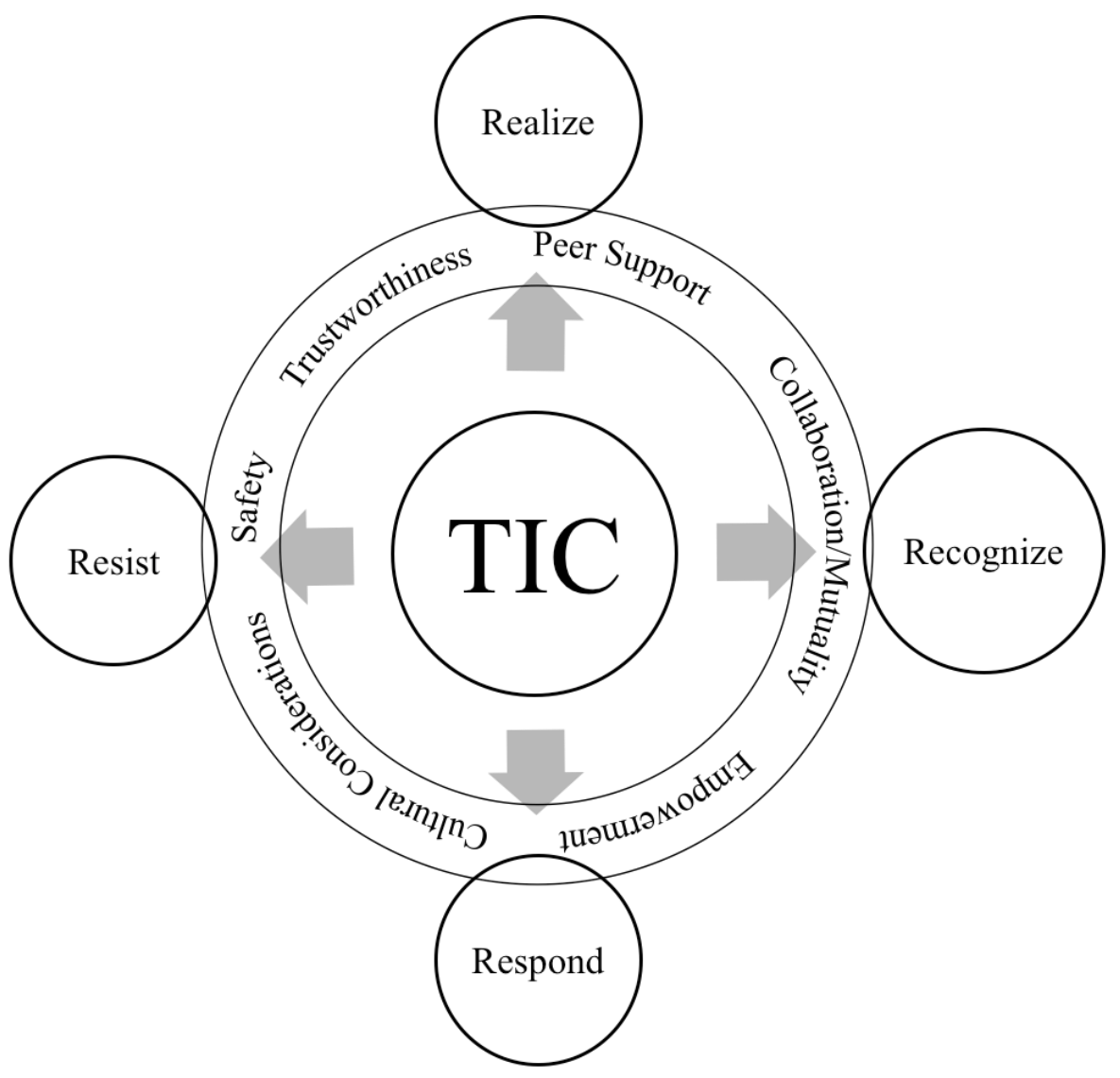

Figure 1. Full model of Trauma-Informed Care, including four key assumptions and six principles that are integrated throughout the process of service delivery (SAMHSA, 2014).

\section{Four key assumptions}

The Substance Abuse and Mental Health Services Administration (SAMHSA) created a trauma-informed approach to treat those who have been exposed to trauma. This approach includes four key assumptions. Therefore, it is assumed that a trauma-informed approach includes these ideas. The four key assumptions to a trauma-informed approach are Realize, Recognize, Respond, and Resist Re-victimization (SAMHSA, 2014). Individuals working with children who have experienced trauma Realize what constitutes trauma and how trauma can impact the children with whom they are interacting (Cavanaugh, 2016; Griffin, Germain, \& Wilkerson, 2012) 
Recognize is the next key assumption to a trauma-informed approach. Those who work with individuals who have been exposed to trauma know how to recognize the signs of trauma in their students (SAMHSA, 2014). Some signs of exposure to trauma are somatic symptoms, poor emotional control, over-reacting to loud noises and/or sudden movements, reduced ability to focus, increased school absences, and decreased reading ability (National Child Traumatic Stress Network, 2008). The result of traumatic experiences, as mentioned in the Trauma Defined section, are deficits in executive functioning skills (Barr, 2018; APA, 2013), establishing and developing relationships (Terrasi \& Crain de Galarce, 2017), and regulating emotions (National Child Traumatic Stress Network, 2008). This assumption is important to recognizing that a child's problem behavior may have been caused by an exposure to trauma.

The third assumption is to Respond. Responding requires mental health service providers to be trained and well versed in an understanding of what these children need from them (SAMHSA, 2014). Interventions implemented to respond to trauma come in different forms. There are interventions that target groups of children, such as the Cognitive Behavioral Intervention for Trauma in Schools, and there are also more intensive individualized interventions such as Trauma-Focused Cognitive Behavioral Therapy and Narrative Therapy. The fourth and final assumption is to Resist Re-victimization. This assumption ties together all four key assumptions to a trauma informed approach, with a final goal of incorporating all of these ideas to support the victim and to help them avoid situations that would result in retraumatization, such as triggering painful memories (SAMHSA, 2014).

\section{Principles of Trauma-Informed Care}

Safety The first principle of safety emphasizes that it is important to develop a safe environment for individuals who have been exposed to trauma (Cavanaugh, 2016; Covington, 
2008; Griffin, Germain, \& Wilkerson, 2012). This principle targets the constant state of hyperarousal that children who are exposed to trauma may experience. In a TIC approach, this principle can be met by instruction in self-regulation, or coping strategies. This is essential because traumatic stress overwhelms the body and can exhaust the child's previously developed coping skills (Arvidson, Kinniburgh, Howard, et al., 2011). Examples of self-regulation strategies that can be taught are self-recognition of physiological reactions, problem solving strategies, relaxation techniques, narrative imaging, and ways to express emotions (Covington, 2008; Arvidson et al., 2011; Griffin et al., 2012). Teaching self-regulation has been shown to help children who have experienced trauma feel safe in their environment (Cavanaugh, 2002; Covington, 2008; Griffin et al., 2012).

Trustworthiness and Transparency The second principle of TIC is trustworthiness and transparency. This principle should be followed by the development and maintenance of strong relationships with students and their families (SAMHSA, 2014). Strong and supportive relationships with teachers has been shown to reduce stress, create a sense of safety, and lead to a positive environment in school for students who have experienced trauma. The students develop a sense of trust for adults in schools who are working to meet their social/emotional, physical health, and academic needs (Rossen \& Hull, 2013). Further, the development of trustworthiness in relationships with students, their families, and educators has led to greater academic success (Bryk \& Schneider, 2003; Klem \& Connell, 2004). Children with trauma backgrounds, who have a positive, trustworthy relationships with an adult are better able to develop effective selfregulation strategies and process their trauma-related stress (Perry, 2009).

Peer Support The third principle of peer support is defined as support and encouragement from others who have experienced trauma and those who are caretakers of one 
who has experienced trauma (SAMHSA, 2014). Peer support is effective in generating feelings of success and self-efficacy for children who have been exposed to trauma (Benight \& Bandura, 2004). In schools bullying and/or cyberbullying is extremely common and negatively effects psychological and physical health (Nixon, 2014). Therefore, creating healthy relationships with others is essential in bolstering future relationship success for individuals who have experienced trauma.

Collaboration and mutuality The fourth principle of collaboration and mutuality emphasizes that everyone who comes into contact with a student who has experienced trauma, including teachers, principals, janitorial staff, and the school receptionist, has the power to help and support this student (SAMHSA, 2014). The caveat is that they need to be taught the skills to do so. In schools, this principle can be met by encouraging positive staff-student communication and relationships. This could also be accomplished by implementing school-wide compassionate approach to teaching and discipline, which trains individuals working with students to be compassionate, use a strengths-based approach, and to become responsive to the social and emotional needs of children (Walkley \& Cox, 2013).

Empowerment, voice, and choice The fifth principle of empowerment, voice, and choice highlights that schools that provide support for individuals who have experienced trauma should encourage staff and client empowerment, and self-advocacy (SAMHSA, 2014; Covington, 2008). To implement this principle into the school setting, staff and students can be allowed time to share their opinions, feelings, and thoughts (Walkley \& Cox, 2013). Schools can enhance this empowerment by validating students' experiences (Covington, 2008); as well as allowing students to take part in making decisions related to their own personal goals, or the schools goals (SAMHSA, 2014). 
Cultural, historical, and gender issues The sixth and final principle is cultural, historical, and gender issues. This principle iterates that when working with individuals it is important to offer services that are culturally competent and allow them to feel safe without having to worry about stereotypes and biases that staff and other clients may have about them (SAMHSA, 2014). This principle embodies the fact that it is important to hear and empathize with a student's and their family's perspective and personal experience. For example, people who come from a minority background may have had limited experiences with mental health professionals or have certain cultural guidelines regarding mental health care in their culture. Schools should make sure to include the perspectives of school personnel, caregivers, and other community leaders of all cultural backgrounds when implementing school policies and procedures (APA, 2008).

\section{Trauma-Informed Approach in Schools}

Given the prevalence of trauma exposure is two out of every three children, (SAMHSA, 2020) it is possible that many students who experience traumatic stress have not been identified and are not receiving intervention services. Therefore, these children do not have any specific support within the school system (Cavanaugh, 2016). The creation of trauma-informed schools would provide support to all students who have been exposed to trauma (RB-Banks, \& Meyers, 2017; Blitz \& Lee, 2015).

Children who have been exposed to trauma may have deficits in learning due to symptoms such as sleep problems, intrusive thoughts, anger outbursts, etc. These symptoms impact executive functioning, attention, memory, cognition, and levels of anxiety (National Child Traumatic Stress Network, 2008). School performance of those who are experiencing traumatic stress can also be impacted. For example, traumatic stress can lead to an overall decrease in 
grade point average (GPA), an increase in school dropout rate, an increased rate of violations of school discipline, and decreased reading achievement. Research suggests that implementing trauma-informed practices in schools will provide support to students to strengthen their academic, social-emotional, and behavioral functioning (Cavanaugh, 2016). When approaching a student through a trauma-informed lens a suggestion to school personnel is to ask "What has happened to the student to shape these behaviors?" instead of "What's wrong with this student?" This shift in interpreting the reason for students' maladaptive behaviors is important for improving outcomes of children who have experienced trauma (Overstreet \& Chafouleas, 2016). A trauma-informed approach can be implemented in schools using SAMHSA's six principles to trauma-informed care and by following the National Child Traumatic Stress Network's ten essential elements of a trauma-informed school system (See Table 1).

Table 1.

Development and Implementation of Trauma-Informed Care in Schools (SAMHSA, 2014).

\begin{tabular}{|lll|}
\hline \multicolumn{1}{|c}{ Assumption } & \multicolumn{1}{c}{ Principle } & \multicolumn{1}{c}{ Essential elements to implement } \\
Realize & Safety & $\begin{array}{l}\text { Identification and assessment of } \\
\text { traumatic stress }\end{array}$ \\
Recognize & Safety & Addressing and treating traumatic \\
& Trustworthiness \& Transparency & stress \\
& Trauma education and awareness \\
& \\
& \\
& & \\
& & (Table Continues) \\
& & \\
&
\end{tabular}




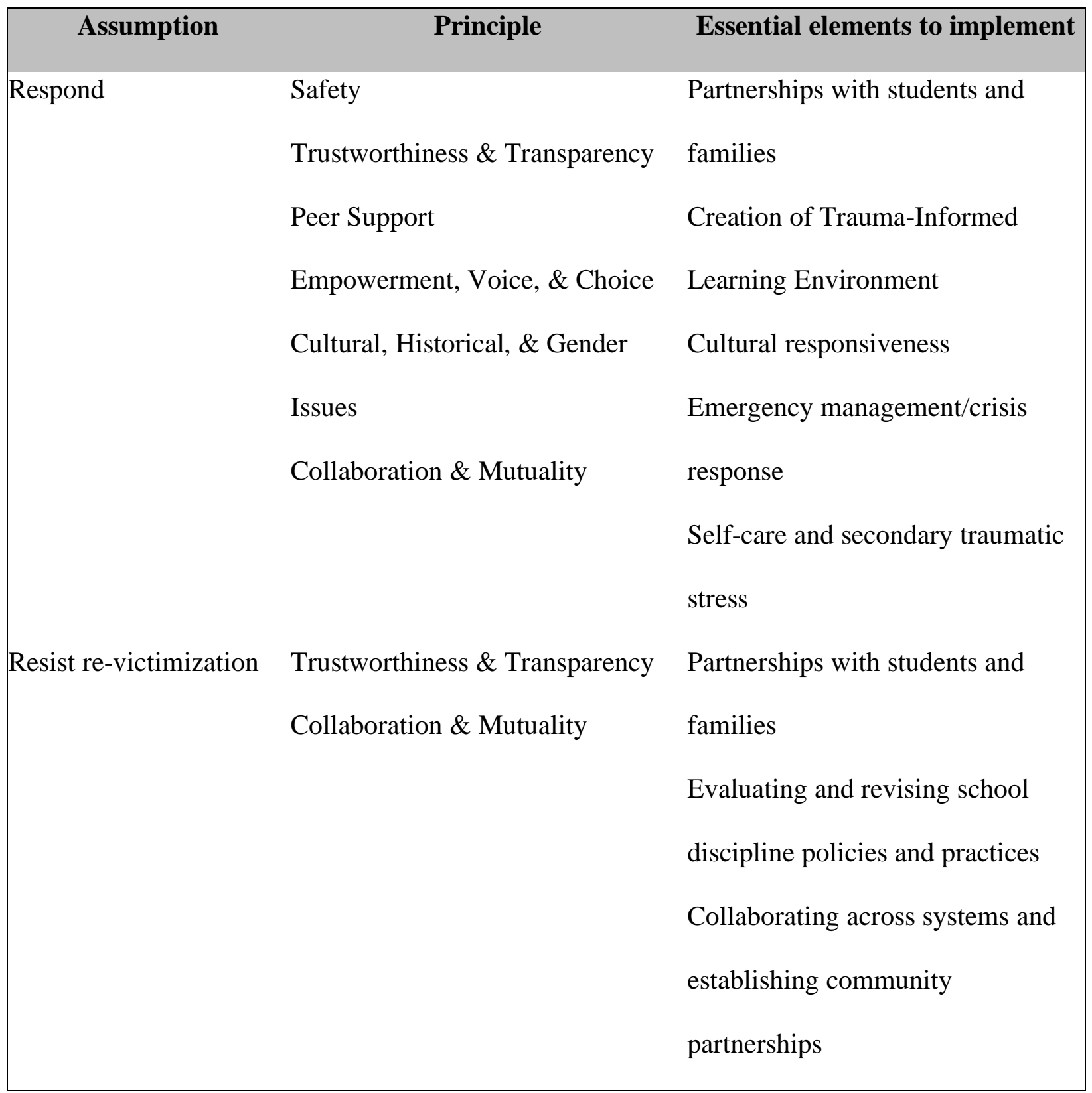

School systems that fully implement a trauma-informed approach have provided training to school staff, community members, students and their families, about how to recognize, realize, and respond to traumatic stress (National Child Traumatic Stress Network, 2017). The National Child Traumatic Stress Network developed ten elements of a Trauma-Informed School System. These ten elements are identifying and assessing traumatic stress, addressing and treating 
traumatic stress, teaching trauma education and awareness, having partnerships with students and families, creating a trauma-informed learning environment (social/emotional skills and wellness), being culturally responsive, integrating emergency/management/crisis response, understanding and addressing staff self-care and secondary traumatic stress, evaluating and revising school discipline policies and practices, and collaborating across systems and establishing community partnerships. This framework takes the six principles of traumainformed care and creates viable strategies for school systems to follow when developing a trauma-informed school. The first element is identifying and assessing traumatic stress. This element emphasizes that trauma-informed schools should have a way of identifying a student who is experiencing traumatic stress. Within this identification process, there should be a plan of action when the data supports that a student is experiencing this stress. The second element is addressing and treating traumatic stress. This element incorporates having a plan to prevent students from exposure to trauma and access to trauma-informed interventions. The third element is teaching trauma education and awareness. Schools should have trainings to help teachers and school staff members gain the skills to realize, recognize, and respond to a child's traumatic stress. The fourth element is having partnerships with students and families. To have a successful trauma-informed school system, families should be included in the decision-making process and planning of the trauma-informed system. The fifth element is creating a traumainformed learning environment. Evidence-based trauma-informed strategies should be implemented throughout the entire school environment, specifically within the social-emotional and behavioral components of the school.

The sixth element is being culturally responsive. In schools this would look like creating culturally sensitive policies in regard to how to respond to trauma. The seventh element is 
integrating emergency management and crisis response. In order to have a trauma-informed school-system, there needs to be a clear policy for how the school will react to crisis situations in order to provide safety for students and reduce the amount of trauma that the students are exposed to. The eighth element is understanding and addressing staff self-care and secondary traumatic stress. Educators should be given ideas and suggestions on ways to take care of themselves, and school administrators should be examples to staff and practice their own selfcare. Further, there should be a policy that indicates who will respond when a traumatic event has occurred within the school community. This element coincides with the element above, because within crisis response, there should also be strategies for this. The ninth element is evaluating and revising school discipline policies and practices. This step emphasizes that schools should specifically identify how they will prevent students from engaging in behaviors that will require discipline. This step also encourages schools to have a strategy to respond to negative behaviors, such as a way to teach the students skills that they need in order to stop engaging in negative behaviors. The tenth element is collaborating across systems and community partnerships. This final element states that it is important for all people and environments in, or associated with, the school to work to together to implement this approach throughout all settings. These ten elements are related to the development and implementation of TIPPS and is explained in the "TIPPS: An Overview" section below.

The structure of the development and implementation of trauma informed care into a school setting can be found in Table 1. The four assumptions are then matched with one or more specific principles that also coincide with one or more steps on how to implement this. This table creates a visual way to see how the assumptions and principles can be applied to implement a trauma-informed approach in schools. 


\section{Group Based Services and Tiered Systems of Intervention}

\section{Response to Intervention}

In the school system, supports are provided to students with social and emotional deficits, including exposure to trauma, through the Response to Intervention (RTI) Model. This model focuses on providing students with appropriate instruction for their academic, social-emotional and behavioral needs. Further, this model allows schools to provide specific services to meet the needs of all students. Within this framework students are provided with high-quality, differentiated instruction through the use of evidence-based practices (Harrison \& Thomas, 2014).

There are three tiers to this system. Tier one is a universal level and provides intervention to all students in the school. This tier works as a preventative measure. The second tier is targeted instruction for small groups of students, who are identified through universal screening processes and are not functioning at the expected level academically, socially, emotionally, or behaviorally. Lastly, Tier 3 is intensive, individualized instruction for the students who are not responding to the Tier 2 small group instruction (Macklem, 2011; Brock et al., 2016). This system allows for all students to receive the supports needed to succeed in school. Within a trauma-informed approach the four assumptions are addressed throughout the Tiers. The six principles are present across each tier in daily practice.

\section{Social Emotional Learning}

To further the emotional and behavioral competence of students, schools target social emotional learning through implementation of policies, programs, and practices. Socialemotional curriculums target the student's ability to manage and understand emotions, achieve goals, show empathy, create positive relationships, and make good decisions. The Collaborative 
for Academic, Social, and Emotional Learning (CASEL) has created five main objectives for social and emotional learning in schools. They are self-awareness, self-management, social awareness, relationship skills, and responsible decision-making. The goal of self-awareness training is to teach the student to recognize their own feelings, thoughts, interpersonal strengths, and have a sense of optimism about themselves. Self-management consists of managing one's emotions, cognitions, and behaviors in order to reach their goals. Social awareness in children is the ability to take other's perspectives, approach others with empathy, and recognize cultural and social norms. Lastly, relationship skills are taught to students to encourage the development of healthy and rewarding relationship skills such as communication, active listening, cooperating, resisting peer pressure, solving conflict, and asking for help. The implementation of social emotional learning curriculums is a crucial component of TIC in schools.

There are Tier 1, universal interventions implemented in schools, such as Second Step (Committee for Children, 2008). However, there is a limited number of Tier 2, targeted interventions implemented in schools. Further, besides the Cognitive Behavioral Intervention for Trauma in Schools [CBITS], interventions developed with a trauma-informed approach are even further limited. CBITS targets a population of students who are experiencing severe traumatic stress that may not have access to resources outside of the school environment (National Child Traumatic Stress Network, 2012). CBITS also includes individual therapy sessions, and parent/teacher sessions. A program such as CBITS does not include students who are at risk for experiencing trauma. TIPPS targets a population of students who are at-risk for trauma, as well as students who have experienced trauma but have reached stabilization. In addition, TIPPS aims to help build students' resiliency to enhance future social-emotional, behavioral, and academic functioning. 


\section{TIPPS: An overview}

There is a need for a program in schools to target students who are at-risk for experiencing trauma. The Trauma-Informed Program for Promoting Success (TIPPS) is a Tier 2 intervention implemented in middle schools that places a specific emphasis on peer relationships due to the high prevalence of peer aggression in middle school students (Wang, Iannotti, \& Nasel, 2009). Furthermore, this program has been developed for the intent of prevention and intervention purposes for youth at risk for trauma symptoms through chronic stress or previous exposure to crises or traumatic events. Therefore, it is intended that the strategies and techniques that are taught within this program will be beneficial for students to have in their "toolbox" when they encounter stressors in high school and later in life. Through the direct instruction of skills related to school, emotions, learning, and friendships, this program intends to promote success throughout the lifespan to increase each student's psychosocial well-being and academic achievement using a trauma-informed approach.

\section{Development}

TIPPS is currently being developed through the process of following the steps of the Participatory Cultural-Specific Intervention Model (PCSIM; Nastasi, Moore, \& Varjas, 2004). This model provides researchers and practitioners with 11 phases to developing an intervention to target a specific population of students. The development of TIPPS follows this model and this dissertation serves as the fourth step (see Figure 2 for all eleven steps specific to TIPPS). 


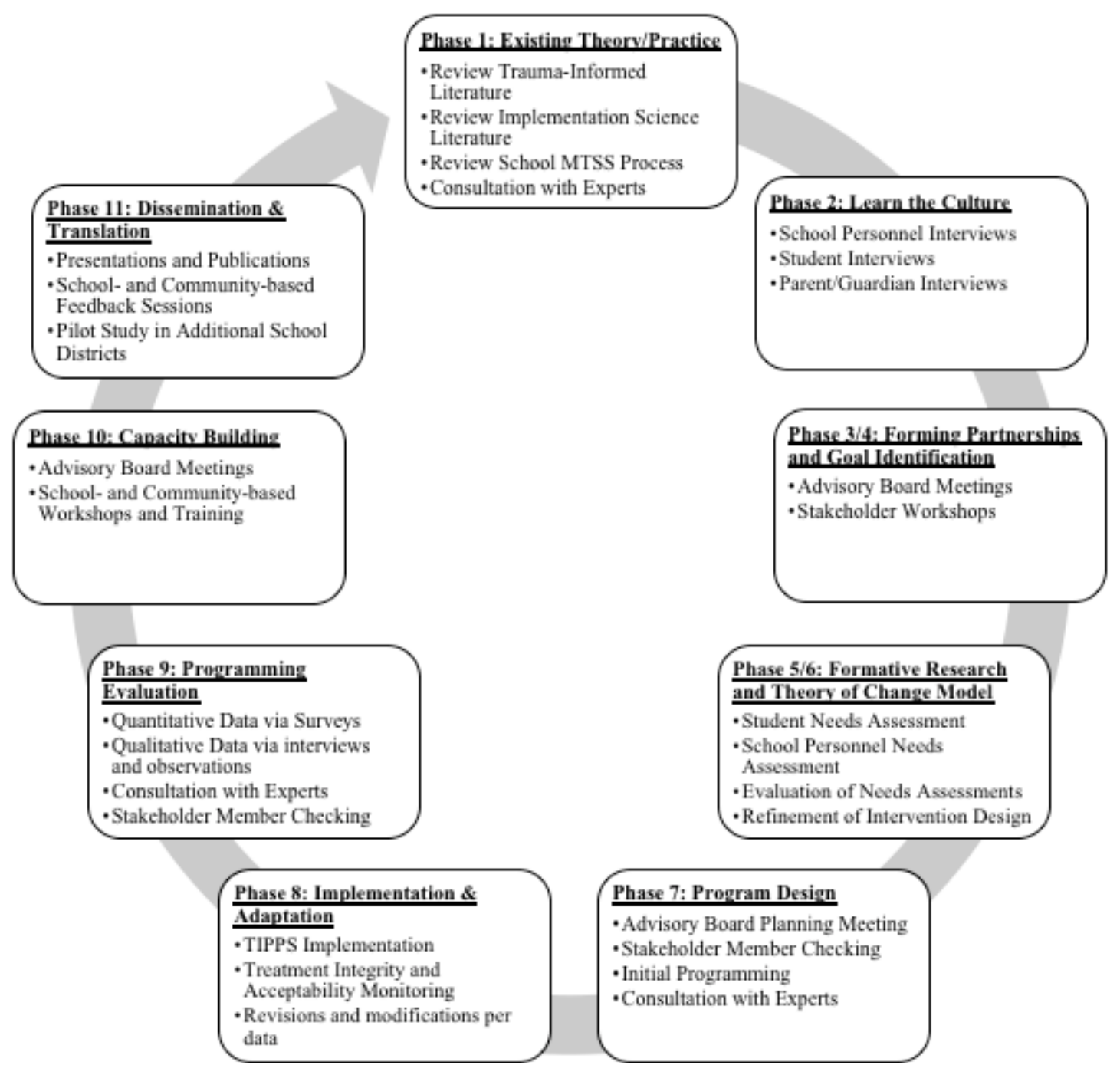

Figure 2. Projected development of TIPPS using the PCSIM framework.

The first two phases of this model were completed by learning about current evidencebased practices on TIC and learning more about the school culture. Through this process, TIPPS staff established a collaborative relationship with the school and started to identify agreed-upon goals for the program (Phase 3 and 4). This trauma-informed program has developed a theory of change through the review of trauma-informed literature and evidence-based practices. The theory of change for TIPPS is that through the completion of this program students will 
strengthen their ability to cope with stressors, improve self-efficacy relating to study skills and academic performance, enhance their self-perceived ability to manage conflict, and create friendships, and strengthen their overall sense of belonging in school by targeting school climate. This program will intervene by helping students with current stressors but will also help to prevent future stressful situations by building resiliency.

\section{Implementation of the Six Principles of Trauma Informed Care}

TIPPS implements the six principles of trauma informed care that are mentioned above. TIPPS addresses the first principle of Safety by teaching topics such as peer victimization, threats to school safety, and the negative impacts of stress in order to help students identify safe and supportive environments at school. Overall, TIPPS will work to provide students with a safe environment that focuses on supporting the students' academic, behavioral, and social-emotional functioning, as well as promoting healthy relationships and ensuring physical safety.

TIPPS follows the second principle of trustworthiness and transparency by facilitating relationships between students and group leaders through relationship building activities, as well as through the consistency of group leaders each week. Within the curriculum, topics will be addressed such as how to talk to and manage relationships with teachers. TIPPS will encourage students to engage in self-help strategies and to seek support from their group leaders and their teachers.

TIPPS follows the principle of peer support by enhancing students' knowledge, attitudes, and behaviors of interpersonal relationships. One of the purposes of the intervention is to facilitate the development of strong and supportive relationships with other group members. Supportive relationships will be encouraged through practicing relationship-building skills. This 
will be implemented within the lessons by talking about problem solving, discussing how others reduce stress at school, and by identifying one's own and other's personal strengths.

In TIPPS, providing trainings for the staff about trauma-informed care follows the principle of collaboration and mutuality. This program focuses on problem solving through scenarios that the students in the group have experienced. Therefore, the students can work together to brainstorm how to support each other in the school environment. At TIPPS the program coordinators will be working closely with the school counselors, in order to communicate tips and strategies for implementing a trauma-informed approach into the school environment.

TIPPS emphasizes the principle of empowerment, voice, and choice by allowing students to share their story through narrative activities. In the program, this may look like group problem solving through situations in which they feel they need to speak to a teacher or staff member. And, through the discussion of self-advocacy strategies to use when there is a conflict in a relationship. These processes will help students to identify and expand on their strengths.

TIPPS meets the principle of cultural, historical, and gender issues by providing a safe space for students of all ethnic, racial, gender, sexual orientations, socioeconomic statuses, religious background, etc. The evidence-based lessons are created to be culturally sensitive, and group leaders are trained to listen to students and empathize with their experiences. All of the staff works together to ensure that TIPPS is a culturally responsive intervention.

\section{Implementation of the Ten Essential Elements of a Trauma-Informed School System}

The TIPPS intervention is implemented into schools using the Ten Essential Elements of a Trauma-Informed School System as a guide to implementation. The first element is identification and assessment of traumatic stress. The school counselors at each school identify 
students for the TIPPS program. The students are identified through a variety of sources, a few being teacher report, parent report, student report, and social-emotional screeners. The second element is addressing and treating traumatic stress. The TIPPS intervention directly teaches emotional management and problem-solving strategies to students to help manage current stressors, foster resiliency, and resist re-victimization. The third element is teaching trauma education and awareness. TIPPS holds trainings for group leaders to learn how to view children through a trauma-informed lens, how to implement trauma-informed activities, and how to support children who have experienced trauma. In the future, TIPPS plans to hold trainings for school staff as well. The fourth element is having a partnership with students and families. This is implemented by requiring families of students who are participating in TIPPS to sign a permission form. Further, these families are able to gain information about the program at any time. In the future, it is the hope that TIPPS will be able to incorporate more family involvement into the curriculum. The fifth element creating a trauma-informed learning environment to support social/emotional skills and wellness. The TIPPS intervention is implemented to help develop student's social/emotional skills and build resiliency.

The sixth element is being culturally responsive. This is implemented by allowing TIPPS to be a safe space for students of all identities. Group leaders are also trained to provide culturally responsive care, whether that be responding to culturally fueled sources of conflict between group members or problem-solving any conflicts that may arise. The seventh element is integrating emergency management/crisis response. This was implemented by consulting with school staff (counselor/psychologist) when students were experiencing extreme emotions. This will be implemented further in the future by offering crisis consultation and training for schools that are implementing the TIPPS program. The eighth element is understanding and addressing 
staff self-care and secondary traumatic stress. This is implemented by training the group leaders of TIPPS how to practice their own self-care and ways to support themselves, while also providing the highest quality care for the students. The ninth element, evaluating and revising school discipline policies and practices. This is implemented within the TIPPS curriculum, by student development of rules and consequences. Further, there are specific strategies that the group leaders use in order to maintain these rules such as the good behavior game. The good behavior game is a classroom behavior management strategy that has been shown to prevent problems in the classroom and promote positive development (Kellam, Mackenzie, Brown, Poduska, Wang, Petras, \& Wilcox, 2011). The tenth element is collaborating across systems and community partnerships. The TIPPS intervention is a community partnership with the school system and the University who implements this intervention.

\section{The Four Components}

The TIPPS curriculum is designed to target the areas of School climate (S), Emotion regulation $(\mathrm{E})$, Learning behaviors $(\mathrm{L})$, and Friendships $(\mathrm{F})$, which is known as the SELF acronym. This was designed based on Blitz \& Lee's (2015) model of SELF, which is safety, emotions, learning and family. TIPPS focuses on school and friendships due to the fact that this is a Tier 2 intervention implemented in the school environment. The program emphasizes the experiences that students have at school and with their friends. These four areas were developed through trauma literature that emphasizes that students who are at-risk for, or have experienced trauma, would benefit from specific instruction in biological responses to stress, learning behaviors, social competency, empowerment, and culturally responsive teaching styles (Blitz \& Lee 2015; SAMHSA, 2014). 
Each component has lessons that target that specific component, the lessons under each component includes a role-play activity, a narrative portion, instruction on adaptive coping, and an identification of strengths section. During the role-play section, students will act out a strategy that they have learned. After this role-play their peers and group leaders can provide them with feedback. This strategy has been shown to be effective in strengthening students understanding of the skills they have learned, specifically when related to peer victimization. Further, roleplaying has been shown to facilitate student understanding of strategies and concepts (Salmivalli, 2014; Westrup \& Planander, 2013). The second strategy used in TIPPS will be a trauma narrative. A trauma narrative is a description of the events that have occurred through writing, drawing, or speaking. The thoughts and feelings experienced during the event are included in the narrative. The use of a narrative to process through events that have occurred has been proven to be effective in reducing trauma symptoms (Deblinger, Mannarino, Cohen, Runyon, \& Steer, 2011). In TIPPS, the narrative component will be used so that students have an opportunity to share and process their experiences, but this will also be used by providing students with stories of fictional others in which they may discuss and implement the strategies they have been learning in the fictional situation. The third strategy used in TIPPS will be direct instruction of adaptive coping strategies. The instruction of adaptive coping strategies for students who have been exposed to trauma contributes to increased resilience and ability to handle chronic stressors (Cicchetti \& Rogosch, 2009). Identifying strengths, the last strategy, is another way to increase resilience. Learning to identify one's own strengths helps to reduce the impact of current and future stressors (Padesky \& Mooney, 2012; Seligman, 2002). Through role-playing, narrative strategies, adaptive coping, and strengths identification, the four components of school climate, emotion regulation, learning behaviors, and friendships will be addressed in the curriculum. 
School climate is defined as how students interpret the respectfulness and fairness of school staff, as well as their own sense of belonging within the school (Cook et al., 2010). An ecological perspective should be used when considering school climate (Jordan \& Austin, 2012). The experiences that students have within, as well as outside of, the school environment contribute to the school's overall climate. TIPPS plans to encourage a positive school climate by increasing school connectedness, increasing group members perceptions of school safety, and facilitating positive relationships between group members and school personnel. The lessons that specifically target enhancing school climate are "Bystanders" and "School Maps". The Bystander lesson works to increase students' perceptions of what to do when they see bullying occurring in their school. The School Maps lesson allows students to identify safe and unsafe places in their school.

Affective education is helpful in teaching strategies for identifying and managing emotions as well as managing the body's stress response (Blitz \& Lee, 2015). In schools, emotion regulation instruction can help children manage their response to interpersonal conflict, such as bullying (Tenenbaum, Parris, Varjas, \& Meyers, 2011; Parris, Varjas, Meyers, \& Cutts, 2012). In the TIPPS curriculum, emotion regulation instruction will be targeted through the "Body Map" and "Problem-Solving" lessons. The Body Map lesson will target increasing students' knowledge about emotions, while the Problem-Solving lesson will increase student's repertoire of coping strategies.

Learning Behaviors are defined as academic and cognitive skills necessary to succeed in the classroom. Rossen \& Hull (2013) stated that in order to foster student academic achievement in students exposed to trauma, a student must be able to focus, comprehend, and organize information learned in the classroom. Therefore, TIPPS teaches students study skills, techniques 
to improve focus, and organizational tactics to facilitate the improvement of academic functioning. In this section, TIPPS builds these skills by learning how to reduce academic stress, identify personal strengths, and apply test-taking strategies. The lessons that will be implemented in this section are "Stop, Drop, and Roll" and "Study Skills." The Stop, Drop, and Roll lesson reviews how our body responds to stress, and strategies we can use in the classroom to combat this stress. The Study Skills lesson teaches students techniques for studying such as planning, organization, and time management, as well as test taking strategies.

Exposure to high levels of toxic stress can lead to deficits in friendship building (Odgers \& Jaffee, 2013). Social support has been shown to reduce stress and depression, and improve health outcomes (Benight \& Bandura, 2004; Buhrmester, 1990). Further, lack of friendships and interpersonal conflicts among students, such as bullying, can exacerbate students' stress levels and negatively influence school climate. Therefore, the friendship section of TIPPS will consist of two lessons "Empathy and Peer Victimization" and "Friendship Mountain." These lessons will focus on identifying friendships, establishing empathy, decreasing peer victimization, and increasing collaborative relationships.

Table 1 provides a depiction of the TIPPS curriculum. There are five base lessons that are general trauma-informed lessons, that help students build a foundation for the lessons about School climate, Emotion regulation, Learning behaviors, and Friendships (SELF). There are five SELF lessons in the current implementation of the intervention. Due to limited time, the curriculum had to be adapted from 14 lessons to 10. Therefore, the learning behaviors lessons were removed from the curriculum and learning behavior techniques and strategies were integrated throughout the other lessons. In this table, the strategies used in each of the SELF lessons is reported. Lastly, the table states goals and objectives of each lesson. 
Table 2.

TIPPS Curriculum.

\begin{tabular}{|c|c|c|c|c|c|}
\hline Week & Lesson & Component & Strategy & & Goals/Objectives \\
\hline 1 & Welcome & Base & General & 1. & $\begin{array}{l}\text { Begin to develop } \\
\text { group rapport. } \\
\text { Establish group } \\
\text { expectations and } \\
\text { consequences. }\end{array}$ \\
\hline 2 & Tale of Two Tigers & Base & General & 2. & $\begin{array}{l}\text { Increase problem } \\
\text { solving behaviors } \\
\text { Increase personal } \\
\text { awareness of one's } \\
\text { body and stress- } \\
\text { inducing situations }\end{array}$ \\
\hline 3 & $\begin{array}{l}\text { Problem Solving } \\
\text { Model }\end{array}$ & Base & General & 1. & $\begin{array}{l}\text { Increase knowledge } \\
\text { on how to solve } \\
\text { problems }\end{array}$ \\
\hline & & & & 2. & $\begin{array}{l}\text { Increase team } \\
\text { building skills } \\
\text { Increase assertive } \\
\text { communication }\end{array}$ \\
\hline 4 & Body scanning & $\begin{array}{l}\text { Emotion } \\
\text { Regulation }\end{array}$ & $\begin{array}{l}\text { Role play \& } \\
\text { Narrative }\end{array}$ & 1. & $\begin{array}{l}\text { Increase } \\
\text { understanding of } \\
\text { one's own emotions }\end{array}$ \\
\hline & & & & 2. & $\begin{array}{l}\text { Increase adaptive } \\
\text { coping with } \\
\text { emotions }\end{array}$ \\
\hline 5 & School Maps & School Climate & Role-play \& & 1. & $\begin{array}{l}\text { Increase perception } \\
\text { of school safety }\end{array}$ \\
\hline & & & $\begin{array}{l}\text { Identification of } \\
\text { Strengths }\end{array}$ & 2. & $\begin{array}{l}\text { Facilitate positive } \\
\text { relationships with } \\
\text { school staff }\end{array}$ \\
\hline 6 & Empathy and Peer- & Friendships & Role-play \& & 1. & $\begin{array}{l}\text { Decrease peer } \\
\text { victimization }\end{array}$ \\
\hline & Victimization & & Adaptive Coping & 3. & $\begin{array}{l}\text { Increase empathetic } \\
\text { statements } \\
\text { Increase assertive } \\
\text { communication }\end{array}$ \\
\hline
\end{tabular}

(Table Continues) 


\begin{tabular}{|c|c|c|c|c|c|}
\hline Week & Lesson & Component & Strategy & & Goals/Objectives \\
\hline 7 & Body Maps & $\begin{array}{l}\text { Emotion } \\
\text { Regulation }\end{array}$ & $\begin{array}{l}\text { Adaptive Coping } \\
\& \text { Identification } \\
\text { of Strengths }\end{array}$ & 1. & $\begin{array}{l}\text { Increase affective } \\
\text { knowledge } \\
\text { Increase self- } \\
\text { awareness }\end{array}$ \\
\hline 8 & Friendship Mountain & Friendships & $\begin{array}{l}\text { Narrative \& } \\
\text { Identification of } \\
\text { Strengths }\end{array}$ & 1. & $\begin{array}{l}\text { Increase personal } \\
\text { awareness } \\
\text { Increase } \\
\text { collaborative } \\
\text { relationships }\end{array}$ \\
\hline 9 & Agree to Disagree & Base & General & 1. & $\begin{array}{l}\text { Increase problem } \\
\text { solving strategies } \\
\text { Increase } \\
\text { collaborative } \\
\text { relationships } \\
\text { Increase assertive } \\
\text { communication }\end{array}$ \\
\hline 10 & Review & Base & General & 3. & $\begin{array}{l}\text { Review SELF. } \\
\text { Establish ways to } \\
\text { continue to use these } \\
\text { skills in the future. }\end{array}$ \\
\hline
\end{tabular}

\section{Research Questions and Hypotheses}

Students will complete pre- and post- group self-report questionnaires to assess their perception of their school climate, emotion regulation strategies, learning behaviors, and friendships. Further, student school records will be examined to assess the change in student academic performance and student discipline referrals. This will be the first study to evaluate the effectiveness of the TIPPS. It is anticipated that TIPPS will enhance students' perceptions of their school climate, emotion regulation strategies, learning behaviors, and friendships, while also increasing their academic performance and decreasing discipline referrals. This will be assessed by examining changes in ratings of participants in the treatment condition (TIPPS) to those of a comparison group (no TIPPS). 


\section{Research Question 1}

Is there a difference between comparison and treatment group scores at post-test on the Child Post-Traumatic Stress Disorder Symptoms Scale after controlling for pre-test score, school, gender and grade?

Hypothesis 1 Given previous research that trauma-informed practices reduce PostTraumatic Stress Disorder Symptoms, we expect that participants in the treatment condition those who receive TIPPS - will experience fewer symptoms of Post-Traumatic Stress Disorder at post-test than those in the comparison group who do not receive TIPPS.

\section{Research Question 2}

Is there a difference between comparison and treatment group scores at post-test on students' perceptions of school climate after controlling for pre-test score, school, gender and grade?

Hypothesis 2 Given previous research that trauma-informed practices improve school climate, we expect that participants in the treatment condition - those who receive TIPPS - will report more favorable perceptions of school climate at post-test than those in the comparison group who do not receive TIPPS.

\section{Research Question 3}

Is there a difference between comparison and treatment group at post-test on students' perceptions of their emotion regulation strategies after controlling for pre-test score, school, gender and grade?

Hypothesis 3 Given previous research that trauma-informed practices improve students' perception of their use of emotion regulation, we expect that participants in the treatment condition - those who receive TIPPS - will report more favorable perceptions of their use of emotion regulation at post-test than those in the comparison group who do not receive TIPPS. 


\section{Research Question 4}

Is there a difference between comparison and treatment group at post-test on students' perceptions of their learning behaviors after controlling for pre-test score, school, gender and grade?

Hypothesis 4 Given previous research that trauma-informed practices improve learning behaviors, we expect that participants in the treatment condition - those who receive TIPPS will report more positive perceptions of their perceptions of their learning behaviors at post-test than those in the comparison group who do not receive TIPPS.

\section{Research Question 5}

Is there a difference between comparison and treatment group at post-test on students' perceptions of their friendships after controlling for pre-test score, school, gender and grade?

Hypothesis 5 Given previous research that trauma-informed practices improve friendships, we expect that participants in the treatment condition - those who receive TIPPS - will report more favorable perceptions of their friendships at post-test than those in the comparison group who do not receive TIPPS.

\section{Research Question 6}

Is there a difference between comparison and treatment group at post-test on student discipline referrals?

Hypothesis 6 Given previous research that trauma-informed practices reduce student discipline referrals, we expect that participants in the treatment condition - those who receive TIPPS - will experience fewer discipline referrals than those in the comparison group who do not receive TIPPS. 


\section{Research Question 7}

Is there a difference between comparison and treatment group at post-test on students' academic performance after controlling for baseline performance, school, gender and grade?

Hypothesis 7 Given previous research that trauma-informed practices improve student academic performance, we expect that participants in the treatment condition - those who receive TIPPS - will score higher on the Measures of Academic Progress (MAP) tests in English and Math at post-test than those in the comparison group who do not receive TIPPS. 


\section{CHAPTER III: METHODS}

\section{Participants}

The participants were 51 middle school students in grades six through eight. There were 28 participants in the control group and 23 in the treatment group. There were seven intervention groups each semester and about 5 students in each group. A $\mathrm{G}^{*}$ Power analysis was completed to determine the power for this repeated measures ANOVA with within and between subject interactions. With 51 participants, the power is .94 , so there is a $94 \%$ chance to find a moderate (f=.25) effect size (Faul, Erdfelder, Lang, \& Buchner, 2007). Participants were recruited from local middle schools in Bloomington-Normal, Illinois, with the help of school counselors.

\section{Measures}

\section{Screener}

Prior to assigning students to their group they completed the Child Post-Traumatic Stress Disorder Symptoms Scale (CPSS; Foa, Johnson, Feeny, \& Treadwell, 2001). The scale can be found in Appendix A. This scale is designed for children ages 8-18. Part one of the scale asks 17 questions relating to the symptom severity of Post-Traumatic Stress Disorder (PTSD) in the DSM-IV, and part two asks 7 questions about the effect of these symptoms on their daily social relationships, emotional well-being, and academic functioning. The CPSS has high internal consistency for the total scale ( $\alpha=.88$; Meyer, Gold, Beas, Young, \& Kassam-Adams, 2015). Sample items include "Having upsetting thoughts or images about the event that came into your head when you didn't want them to," "Not feeling close to people around you," and "Having trouble falling or staying asleep." Overall this has been determined to be a useful tool for evaluating symptomology of PTSD and the effect of that symptomology on the child's daily life (Meyer et al., 2010; Foa et al., 2001). This screener served as the determinant in whether or not 
students will be included in the study. Only those participants that exceeded the cut-off score of 25 on part one and obtain at least a 3 on part two were included in the study. This ensures that participants experience stress related to trauma at least once a week across a range of symptoms while also impacting their life in at least three of the seven areas.

\section{School Climate}

Participants were administered the US Department of Education School Climate Scale as a pre- and post-test measure of perceptions of school climate (DOE-SCS; National Center for Education for Statistics, 2017). The scale can be found in Appendix B. There are 15 items in which students rate their answers as strongly agree, agree, disagree, and strongly disagree. This scale has high internal consistency $(\alpha=.91)$. This scale assesses perceptions of school climate through students' ratings on statements such as "My teachers make me feel good about myself" and "Students at this school get along well with each other." Further, the scale has questions specific to bullying and cyberbullying such as "Students at this school are often bullied," and "Students often spread mean rumors or lies about others at this school on the internet."

\section{Emotion Regulation}

Participants were administered the Emotion Regulation Questionnaire for Children and Adolescents (ERQ-CA) as a pre and post-test measure of emotion regulation (Gullone \& Taffe, 2011). The scale can be found in Appendix C. There are ten items, six of which assess Cognitive Reappraisal (CR), and four of which assess Expressive Suppression (ES). Participants rated items on a 5-point Likert scale (strongly disagree to strongly agree). The EQR-CA has high internal consistency ( $\alpha=.79$ for Reappraisal, 0.73 for Suppression). Sample items include "When I want to feel happier, I think about something different," "I keep my feelings to myself," and "I control my feelings about things by changing the way I think about them. 


\section{Learning Behaviors}

Participants were administered a curriculum-based measured called the Learning Skills Scale that measures their learning behaviors such as test taking skills and feelings of test anxiety. The scale can be found in Appendix D. Participants rate items on a 5-point Likert scale (strongly disagree to strongly agree). Examples of items are "I have difficulty managing my stress before a test," and "There are strategies I can use when I become overwhelmed with my homework."

\section{Friendships}

Participants were administered the Conflict Management Questionnaire (CMQ) as a preand post-test measure of their social relationships (Gaumer Erickson \& Noonan, 2018). The scale can be found in Appendix E. This questionnaire is composed of 21 items that measure response to conflict, understanding of conflict, and application of management of a conflict. This scale is intended for middle and high school students. Items are rated on a 5-point, Likert scale. The scale ranges from $(1=$ Not very like me, to $5=$ Very like me $)$. The scale has been found to be moderately reliable $(\alpha=.87$ ) (Gaumer Erickson, A.S., Soukup, J.H., Noonan, P.M., \& McGurn, L., 2018). Sample items are "I have thought about how I normally respond to conflicts," "In an argument, I try to understand the other person's point of view," "When I'm involved in a disagreement, I stop and think about what I should say or do.”

\section{Record Review}

A record review was conducted to determine the change in the participants discipline record and academic performance throughout the intervention. The counselors reported student Measure of Academic Progress (MAP) results on math and reading sections pre and post intervention. The counselors also reported number of discipline referrals the students' received during the intervention period. 


\section{Procedure}

The undergraduate and graduate student researchers who ran TIPPS groups will received training on trauma-informed care and the TIPPS protocol. All students at both middle schools were administered the PTSD screener. Students who exceeded the cut-off score and or were referred by the school counselors were be eligible to participate in this study. The students who were eligible for the study then completed all of the additional scales. They were randomly assigned to either the treatment or the comparison group (see Figure 3). There was one round of TIPPS intervention that occurred in the Fall of 2019. All students were administered the scales again at the end of Fall 2019. The second round of the TIPPS intervention was implemented in Spring of 2020. Due to schools closing because of the COVID-19 global pandemic, the Spring 2020 TIPPS intervention ended after 6 lessons were administered. The additional lessons were presented to students through a take-home packet created by the TIPPS team.
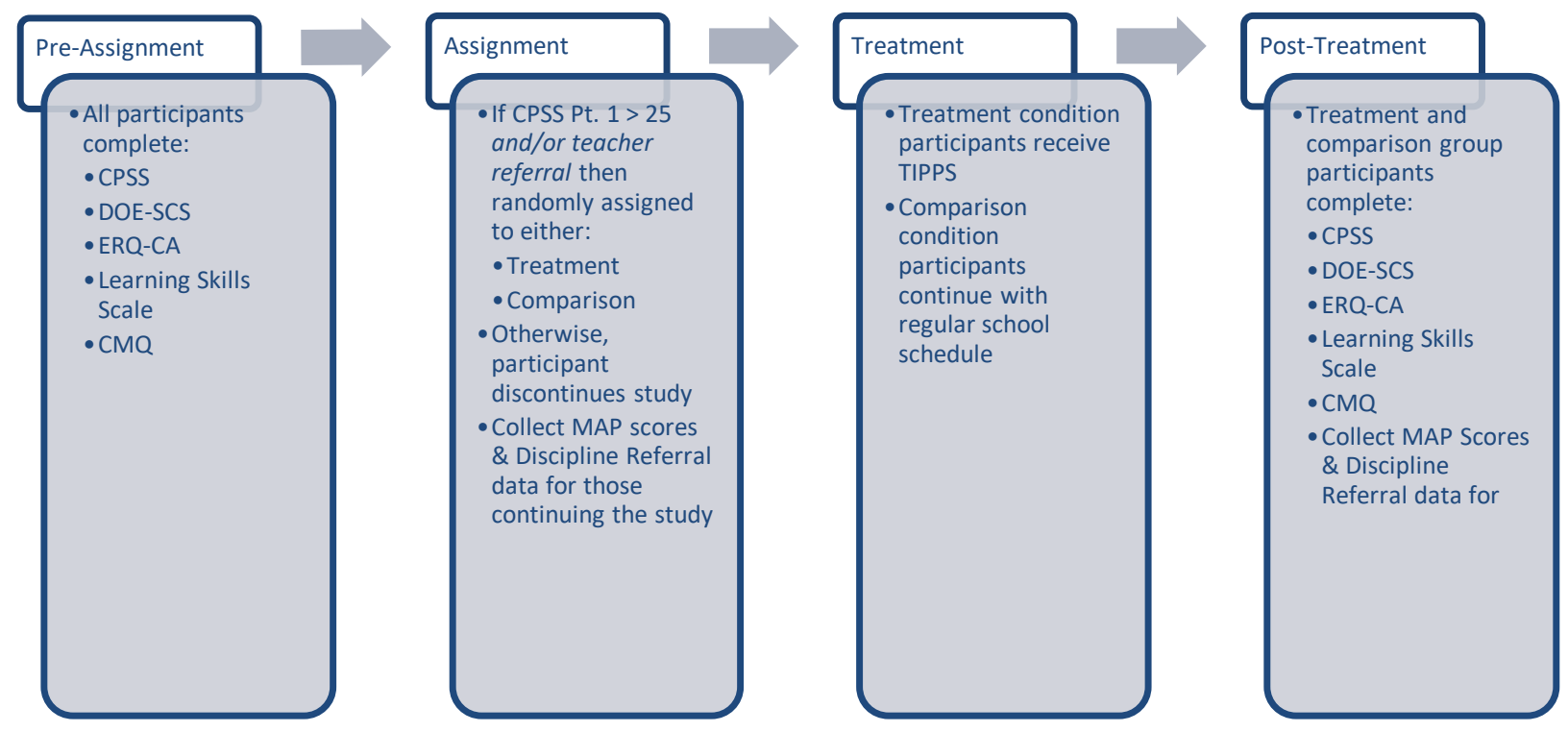

Figure 3. Procedures. 


\section{CHAPTER IV: ANALYSES}

\section{Measures of Internal Consistency}

Cronbach's alphas were computed for each subscale of the Child Post-Traumatic Stress Disorder Symptoms Scale (CPSS; Foa, Johnsen, Feeny, \& Treadwell, 2001), US Department of Education School Climate Scale (National Center for Education for Statistics, 2017), Emotion Regulation Questionnaire for Children and Adolescents (Gullone \& Taffe, 2011), the Conflict Management Questionnaire (Gaumer Erickson \& Noonan, 2018) and a curriculum-based survey for learning behaviors to determine internal consistency of the items (Table 3). Adequate internal consistency was defined as $\alpha \geq 0.70$. The expressive suppression subscale of the Emotion Regulation Questionnaire was removed due to inadequate reliability. One item in the CPSS Part A scale was omitted to improve reliability for this scale.

Table 3.

Fall and Winter Cronbach Alphas for Subscales of the Emotion Regulation Questionnaire, Conflict Management Questionnaire, Department of Education School Climate Scale, Learning Behaviors Scale, and Child Post Traumatic Stress Disorder Symptoms Scale

\begin{tabular}{|c|c|c|c|}
\hline & Fall $\alpha$ & Winter $\alpha$ & $N$ of items \\
\hline \multicolumn{4}{|l|}{ Emotion Regulation Questionnaire } \\
\hline Cognitive Reappraisal & .807 & .850 & 6 \\
\hline Conflict Management Questionnaire & .824 & .727 & 22 \\
\hline Department of Education School Climate Scale & .867 & .880 & 15 \\
\hline Learning Behaviors Scale & .533 & .607 & 5 \\
\hline \multicolumn{4}{|l|}{ Child Post-Traumatic Stress Disorders } \\
\hline \multicolumn{4}{|l|}{ Symptoms Scale } \\
\hline Part A & .772 & .562 & 16 \\
\hline Part B & .658 & .768 & 7 \\
\hline
\end{tabular}

\section{Group Differences Analysis}

\section{Demographic Differences}

First, the differences in demographics between the experimental and control group were examined. Chi Square tests examining the independence between treatment condition and 
participants' school, grade, and free and reduced lunch qualifications did not indicate any significant associations between group assignment and these variables. Chi square tests examining the independence between treatment condition and gender did indicate a marginally significant association between condition and gender. There were 5 males in the experimental group and 13 males in the control group, whereas there were 18 females in the experimental group and 14 females in the control group, $\chi^{2}=(1, \mathrm{~N}=23)=3.76, \mathrm{p}=.053$ (see Table 4$)$.

Table 4.

Chi-Square Tests Examining Demographic Differences of Experimental Group and Control Group

\begin{tabular}{|c|c|c|c|c|c|c|}
\hline & \multicolumn{2}{|c|}{ Experimental } & \multicolumn{2}{|c|}{ Control } & \multirow[b]{2}{*}{$\chi^{2}$} & \multirow[b]{2}{*}{$p$} \\
\hline & $\mathrm{N}$ & Percent & $\mathrm{N}$ & Percent & & \\
\hline School & & & & & .375 & .540 \\
\hline Kingsley & 12 & 52.2 & 17 & 60.7 & & \\
\hline Parkside & 11 & 47.8 & 11 & 39.3 & & \\
\hline Gender & & & & & 3.76 & .053 \\
\hline Male & 5 & 21.7 & 13 & 48.1 & & \\
\hline Female & 18 & 78.3 & 14 & 51.9 & & \\
\hline Grade & & & & & .085 & .959 \\
\hline $6^{\text {th }}$ & 10 & 43.5 & 12 & 42.9 & & \\
\hline $7^{\text {th }}$ & 5 & 21.7 & 7 & 25.0 & & \\
\hline $8^{\text {th }}$ & 8 & 34.8 & 9 & 32.1 & & \\
\hline Free and Red Lunch & & & & & .453 & .501 \\
\hline No & 9 & 52.9 & 14 & 63.6 & & \\
\hline Yes & 8 & 47.1 & 8 & 36.4 & & \\
\hline
\end{tabular}

\section{Pre-test Differences}

One-way analyses of variance (ANOVAs) were used to measure the differences between pre-test scores for the experimental and control group. ANOVAs examining the differences between the pre-test scores on the Child Post-Traumatic Stress Disorder Symptoms Scale (CPSS; Foa, Johnsen, Feeny, \& Treadwell, 2001), US Department of Education School Climate Scale (National Center for Education for Statistics, 2017), Emotion Regulation Questionnaire for Children and Adolescents (Gullone \& Taffe, 2011), the Conflict Management Questionnaire (Gaumer Erickson \& Noonan, 2018), and the curriculum-based survey for learning behaviors did 
not indicate any significant differences between the experimental group and the control group at pre-test (see Table 5).

Table 5.

Differences between the Emotion Regulation Questionnaire, Conflict Management Questionnaire, Department of Education School Climate Scale, Learning Behaviors Scale, and Child Post Traumatic Stress Disorder Symptoms Scale According to Group at Fall

\begin{tabular}{|c|c|c|c|c|c|c|}
\hline & \multicolumn{2}{|c|}{$\begin{array}{l}\text { Experimental }(\mathrm{N} \\
=23)\end{array}$} & \multicolumn{2}{|c|}{ Control $(N=28)$} & \multirow[b]{2}{*}{$F$} & \multirow[b]{2}{*}{$p$} \\
\hline & $M$ & $S E$ & $M$ & $S E$ & & \\
\hline \multicolumn{7}{|l|}{$\begin{array}{l}\text { Emotion Regulation } \\
\text { Questionnaire }\end{array}$} \\
\hline $\begin{array}{l}\text { Cognitive } \\
\text { Reappraisal }^{\mathrm{a}}\end{array}$ & 2.64 & .19 & 3.06 & .19 & 2.11 & .16 \\
\hline $\begin{array}{l}\text { Conflict Management } \\
\text { Questionnaire }\end{array}$ & 3.17 & .13 & 3.28 & .13 & .302 & .587 \\
\hline $\begin{array}{l}\text { Dept of Ed School } \\
\text { Climate }^{b}\end{array}$ & 2.41 & .12 & 2.49 & .12 & .24 & .63 \\
\hline Learning Behaviors ${ }^{\mathrm{a}}$ & 2.98 & .18 & 2.90 & .18 & .11 & .74 \\
\hline \multicolumn{7}{|l|}{$\begin{array}{l}\text { Child PTSD Symptoms } \\
\text { Scale }\end{array}$} \\
\hline Part $A^{b}$ & 1.88 & .08 & 1.99 & .08 & .86 & .36 \\
\hline Part $\mathrm{B}^{\mathrm{a}}$ & .458 & .07 & .384 & .07 & .56 & .46 \\
\hline
\end{tabular}

\section{Analyses of Covariances}

Analyses of Covariance were conducted to determine the differences in participant's post-test responses on the Child Post-Traumatic Stress Disorder Symptoms Scale (CPSS; Foa, Johnsen, Feeny, \& Treadwell, 2001), US Department of Education School Climate Scale (National Center for Education for Statistics, 2017), Emotion Regulation Questionnaire (ERQ) for Children and Adolescents (Gullone \& Taffe, 2011), the Conflict Management Questionnaire (CMQ) (Gaumer Erickson \& Noonan, 2018), the curriculum-based survey for learning behaviors (LBS), Math and Reading Measures of Academic Progress scores; while controlling for pre-test score, school, gender, and grade according to group. The means from the fall scales were substituted for the 
same six participants (11\%) who did not complete the CPSS, US Dept of Education School

Climate Scale, the ERQ, CMQ, and the LBS, in the fall (see table 6). These students did complete all post-test measures. Mean substitution was not used for the missing data for the Math and Reading MAP scores. Analyses of Covariance were examined for each subscale (See Table 7 below).

Table 6. Percentage of missing data substituted using Mean Substitution.

\begin{tabular}{|l|c|}
\hline \multicolumn{1}{|c|}{ Scale } & Percent of Mean Substitution \\
\hline $\begin{array}{l}\text { Child Post Traumatic Stress Disorder } \\
\text { Symptoms Scale }\end{array}$ & $11 \%$ \\
\hline US Dept of Education School Climate Scale & $11 \%$ \\
\hline Emotion Regulation Questionnaire & $11 \%$ \\
\hline Conflict Management Questionnaire & $11 \%$ \\
\hline Learning Behavior Scale & $11 \%$ \\
\hline Reading MAP Scores & $0 \%$ \\
\hline Math MAP Scores & $0 \%$ \\
\hline
\end{tabular}

\section{Post-Traumatic Stress Disorder Symptoms Scale}

The Post-Traumatic Stress Disorder Symptoms scale has two parts, Part A and Part B. There was no significant difference between groups on the CPSS A post-test while controlling for CPSS-A pre-test score, school, gender, and grade, $F(1,50)=.253, p=.617$. There was not a significant difference between groups on the CPSS-B post-test while controlling for CPSS-B pretest score, school, gender, and grade, $F(1,50)=2.70, p=.108$.

\section{Emotion Regulation}

The Emotion Regulation Questionnaire has two subscales, Cognitive Reappraisal and Expressive Suppression. There was no significant difference between groups on the Cognitive Reappraisal post-test while controlling for Cognitive Reappraisal pre-test score, school, gender, and grade, $F(1,50)=.857, p=.360$. 


\section{Conflict Management}

There was no significant difference between groups on the Conflict Management Questionnaire post-test while controlling for pre-test score, school, gender, and grade, $F(1,50)=$ $.070, p=.792$.

\section{School Climate}

There was no significant difference between groups on the Department of Education School Climate Scale post-test while controlling for the Department of Education School Climate Scale pre-test score, school, gender, and grade, $F(1,50)=.091, p=.764$.

\section{Learning Behaviors}

There was no significant difference between groups on the Learning Behaviors Scale post-test while controlling for the Learning Behaviors Scale pre-test score, school, gender, and grade, $F(1,50)=.008, p=. .929$.

\section{Measures of Academic Progress}

There was no significant difference between groups on the English MAP scores post-test while controlling for the English MAP pre-test score, school, gender, and grade, $F(1,42)=.062$, $p=.805$. There was no significant difference between groups on the Math MAP scores post-test while controlling for the Math MAP pre-test score, school, gender, and grade, $F(1,42)=.421, p$ $=.521$. 
Table 7.

ANCOVA comparing participant's responses on the Emotion Regulation Questionnaire, Conflict Management Questionnaire, Department of Education School Climate Scale, Learning Behaviors Scale, the Child PTSD Symptoms Scale, English MAP scores, and Math MAP scores according to group

\begin{tabular}{|c|c|c|c|c|c|c|c|}
\hline & \multicolumn{2}{|c|}{ Experimental } & \multicolumn{2}{|c|}{ Control } & \multirow[b]{2}{*}{$D f$} & \multirow[b]{2}{*}{$F$} & \multirow[b]{2}{*}{$p$} \\
\hline & M & $\mathrm{SE}$ & M & SE & & & \\
\hline \multicolumn{8}{|l|}{ Emotion Regulation } \\
\hline $\begin{array}{l}\text { Cognitive } \\
\text { Reappraisal }\end{array}$ & 2.71 & .17 & 2.94 & .16 & 50 & .857 & .360 \\
\hline $\begin{array}{l}\text { Conflict Management } \\
\text { Questionnaire }\end{array}$ & 3.32 & .10 & 3.29 & .09 & 50 & .070 & .792 \\
\hline $\begin{array}{l}\text { Dept of Ed School } \\
\text { Climate }^{b}\end{array}$ & 2.58 & .11 & 2.62 & .10 & 50 & .091 & .764 \\
\hline Learning Behaviors $^{\mathrm{a}}$ & 3.08 & .14 & 3.10 & .13 & 50 & .008 & .929 \\
\hline \multicolumn{8}{|l|}{$\begin{array}{l}\text { Child PTSD } \\
\text { Symptoms Scale }\end{array}$} \\
\hline Part $A^{a}$ & 1.70 & .11 & 1.78 & .10 & 50 & .253 & 617 \\
\hline Part $B^{b}$ & .38 & .06 & .53 & .06 & 50 & 2.70 & .108 \\
\hline Reading MAP Scores & 219.48 & 1.74 & 220.12 & 1.83 & 42 & .062 & .805 \\
\hline Math MAP Scores & 219.99 & 1.72 & 221.66 & 1.81 & 42 & .421 & .521 \\
\hline
\end{tabular}

\section{Analysis of Behavioral Referrals}

An independent samples t-test was conducted to compare the control group student behavioral referrals to the experimental group behavioral referrals after the intervention was administered. The students in the control group had an average of $3.6(\mathrm{SD}=8.60)$ behavioral referrals whereas the experimental group had an average of $.52(\mathrm{SD}=1.04)$ behavioral referrals. This difference therefore was marginally significant, $t(42)=-1.742, p=.089$. Figure 4 and 5 below shows the differences between the two groups. In the experimental group, $73.9 \%$ of students had zero behavior referrals, $13 \%$ had one, and $13 \%$ had three. In the control group, $66.7 \%$ had zero behavior referrals, $4.8 \%$ had one, $9.5 \%$ had three, $4.8 \%$ had $5,4.8 \%$ had 14 , $4.8 \%$ had 15 , and $4.8 \%$ had 36 . 


\section{Treatment Group Behavior Referrals}

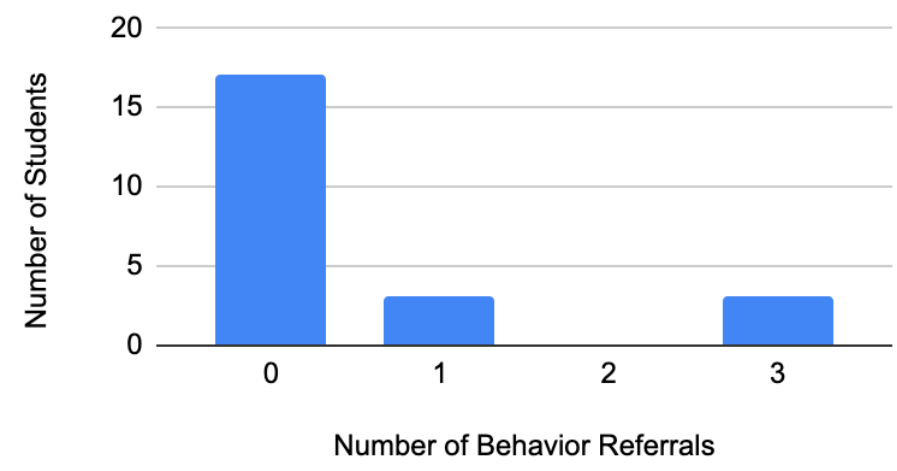

Figure 4. Treatment group behavior referrals.

\section{Control Group Behavior Referrals}

\section{0}

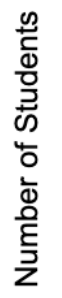

15

10

5

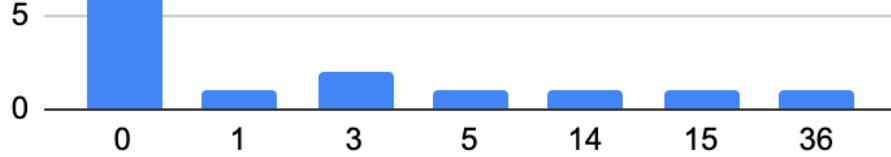

Number of Behavior Referrals

Figure 5. Control group behavior referrals. 


\section{CHAPTER V: DISCUSSION}

The purpose of this study was to examine the effectiveness of a trauma-informed intervention in improving middle school students' perceptions of their PTSD symptoms, school climate, emotion regulation strategies, learning behaviors, and friendships. The study also evaluated the program's impact on the students' academic scores and discipline referrals.

The specific measures used to measure these variables include the Child Post-Traumatic Stress Disorder Symptoms Scale (CPSS; Foa, Johnson, Feeny, \& Treadwell, 2001). The CPSS was used as a screener for participation in the study and as a pre- and post-intervention measure. The CPSS included two parts, Part A measured participant report of PTSD symptoms and Part B measures the impact of those symptoms on the participant's daily lives. The US Department of Education School Climate Scale was used as a pre- and post-test measure of students' perceptions of school climate (DOE-SCS; National Center for Education for Statistics, 2017). This includes questions about teacher-student relationships, student to student relationships, and peer victimization. The Emotion Regulation Questionnaire for Children and Adolescents (ERQCA) as a pre and post-test measure of emotion regulation (Gullone \& Taffe, 2011). The ERQ-CA measures Cognitive Reappraisal, restructuring the impact of emotional situations, and Expressive Suppression, inhibiting emotional expressions. A curriculum-based learning behaviors measure was used to examine participant's perceptions of their test-taking skills and feelings of testanxiety. Finally, the Conflict Management Questionnaire (CMQ) was used as a pre- and post-test measure of students' perceptions of their social relationships (Gaumer Erickson \& Noonan, 2018). This measured students' response to conflict, understanding of conflict, and application of management of a conflict. 
Students' academic and behavioral data was also collected. Students' academic functioning was determined by their Measures of Academic Progress (MAP) scores in reading and math. This data is collected at the beginning of the fall semester, so before TIPPS began, and the beginning of the winter semester, after TIPPS finished. Behavioral data was reported by indicating how many behavioral referrals the students' received during the TIPPS program.

This study sought to determine the effectiveness of a group-based trauma-informed curriculum, the Trauma Informed Program for Promoting Success, implemented with middle school students.

\section{Summary of Findings}

Computations of Cronbach's alphas for each scale and subscales were conducted. Adequate internal consistency ( $\alpha \geq 0.70)$ was indicated within the Cognitive Reappraisal subscale of the emotion regulation questionnaire, the Understand Natural Response subscale of the Conflict Management Scale, the School Climate Scale, and Part A of the CPSS. The following scales had less than adequate internal consistency, the Expressive Suppression subscale of the ERQ $(\alpha=.353)$, the Understand Context $(\alpha=.467)$ and Apply Approach $(\alpha=$ $.469)$ subscales of the CMQ, the Learning Behaviors Scale $(\alpha=.533)$, and Part B of the CPSS ( $\alpha$ $=.658)$.

The final sample consisted of 51 students from 2 middle schools within one district. There were 23 students in the control condition and 28 in the experimental condition. The participants were randomly assigned to treatment and control groups prior to gathering parent permission to participate in the study. Therefore, the groups ended up imbalanced despite random assignment because this depended on which families consented to be in the study. There were no differences between the control and experimental groups based on school, grade, or free 
and reduced lunch status, though findings did indicate a difference between groups based on gender. There were fewer males in the experimental group (21.7\%) than the control group $(48.1 \%)$. It is possible that this gender difference could have impacted the results of the study.

Differences between the scales on pre-test measures were examined. It was determined that there was no difference in control versus experimental group participants ratings on pre-test measures when controlling for school, gender, grade, and free and reduced lunch status.

ANCOVAs were conducted to compare responses on each dependent variable according to group, while controlling for school, gender, grade, and fall score. There were no differences found between groups on any measure. The analyses were run simply omitting people with missing values and the results were similar, with the CPSSB having a marginal effect in the opposite direction from what was hypothesized.

\section{Interpretation of Findings}

\section{Hypothesis one}

The first hypothesis posits that trauma-informed practices work to reduce PTSD symptoms, so participants in the treatment condition will experience a fewer symptoms of PTSD at post-test than those in the control group who did not receive the intervention. The CPSS had two parts, Part A was a report of PTSD symptoms and Part B was a report of the extent to which problems that identified in Part A had gotten in the way in a list of areas of their lives. There was no difference between treatment and control group on Part A. Therefore, the treatment group did not report fewer PTSD symptoms than the control group after the intervention.

Further, the treatment group reported that the symptoms rated in Part A did not get in the way of significantly more areas of their lives post-intervention than did the control group. The areas of life included: doing your prayers, chores and duties at home, relationships with friends, 
fun and hobby activities, schoolwork, relationships with your family, and general happiness with your life. The TIPPS intervention specifically targeted the areas of relationships with friends and family, fun and hobby activities, schoolwork, and happiness with life. Although the NCTSN (2008) reports that trauma-informed interventions implemented in middle schools will provide students with the supports needed to cope with these trauma-symptoms to succeed in social, behavioral and academic settings, this data suggests that students' exposed to trauma-informed interventions may indicate that these symptoms have more of an impact on their lives because the intervention increases their awareness to when problems are impacting their lives. Further, the literature suggests that students' who have experienced or are at risk for experiencing trauma would benefit from instruction in biological responses to stress, learning behaviors, and social competency (Blitz \& Lee, 2015; SAMHSA, 2014). Therefore, it is possible that this intervention increases awareness of how stress is impacting the physical, social, and emotional functioning, but does not change students PTSD symptomology.

\section{Hypothesis two}

The second hypothesis posits that participants in the treatment condition would report more favorable perceptions of school climate at post-test than those in the comparison group who did not receive TIPPS. However, there was no difference found in perceptions of school climate between the treatment and comparison groups. Children with trauma backgrounds, who have trustworthy relationships with adults are better able to manage their stress (Perry, 2009). Though, since the TIPPS intervention was not implemented by individuals who worked at the school, it may have been more difficult for these trustworthy relationships to build feelings of safety at school for the students. 


\section{Hypothesis three}

The third hypothesis posits that participants in the treatment condition would report more favorable perceptions of their use of emotion regulation at post-test than those in the comparison group who did not receive TIPPS. The Emotion Regulation Questionnaire had two subscales:

Cognitive Reappraisal and Expressive Suppression. We removed Expressive Suppression due to inadequate reliability. Therefore, researchers looked at only the cognitive reappraisal subscale. There was no difference found in perceptions of cognitive reappraisal between the treatment and comparison groups. Cognitive Reappraisal is redefining an emotional situation whereas Expressive Suppression is the act of inhibiting your emotions (Gullone \& Taffe, 2011). The TIPPS curriculum focused on general instruction of strategies for identifying and managing emotions, therefore, it is possible that the scale did not measure what the intervention was targeting.

\section{Hypothesis four}

The fourth hypothesis suggests that participants in the treatment condition would report more favorable perceptions of their learning behaviors at post-test than those in the comparison group. There was no difference found in perceptions of learning behaviors between the treatment and comparison groups. This learning behaviors scale was a curriculum-based measure, therefore, it may have been more effective to use a research-based scale that evaluates students' learning behaviors such as study skills and test anxiety. Further, alterations to the curriculum were made due to time constraints and the two lessons that targeted learning behaviors were removed from the final curriculum. 


\section{Hypothesis five}

The fifth hypothesis suggests that participants in the treatment condition would report more favorable perceptions of their friendships at post-test than those in the comparison group. Research indicates that chronic stress can lead to deficits in friendship building (Odgers \& Jaffee, 2013) and lack of social support with same-age peers in schools exacerbates stress and leads students to have a negative perception of the school environment. Therefore, direct instruction of emotion regulation strategies helps children to manage interpersonal conflict (Tenenbaum, Parris, Varjas, \& Meyers, 2011; Parris, Varjas, Meyers, \& Cutts, 2012). The TIPPS intervention taught explicit instruction of emotion regulation strategies, establishing empathy, and increasing collaborative relationships. This hypothesis was tested using the Conflict Management Questionnaire. There was no difference found in perceptions of Conflict Management between the treatment and comparison groups.

\section{Hypothesis six}

The sixth hypothesis suggests that participants in the treatment condition would experience greater reduction in their discipline referrals than those in the comparison group. There was a marginally significant difference in the expected direction found in discipline referrals between the treatment and comparison groups. Trauma symptoms impact children's behavioral functioning, therefore implementation of trauma-informed strategies supports students behavioral functioning (Cavanaugh, 2016).

\section{Hypothesis seven}

The seventh hypothesis suggests that participants in the treatment condition would demonstrate benefits to their academic performance compared to those in the comparison group. Academic performance was assessed by examining students' fall and winter MAP scores for 
reading and math. Although research indicates that the implementation of trauma-informed supports into schools would strengthen students' academic performance (Cavanaugh, 2016), there was no difference found in reading or math MAP scores between the treatment and comparison groups.

\section{Strengths and Limitations}

\section{Strengths}

There are many strengths of the current study. This study was both an experiment and an applied intervention study. Therefore, this study met a need in the school district as a way of implementing tier 2 services to students who are at-risk for experiencing trauma, while also randomly assigning participants into control and treatment groups. There was a screener for participation in the intervention in order to target a high-needs population of students. Use of a school-wide screener is an effective strategy to identify students who need Tier 2 supports (Anderson \& Borgmeier, 2010). The intervention was designed and implemented following a trauma-informed approach, while also considering the needs of the particular schools.

Prior to Fall 2019, the TIPPS program was piloted during the 2017-18 and 2018-19 school years. The researchers used the data gathered from the pilot studies, along with literature emphasizing trauma-informed care to create the evidence-based intervention.

A strong partnership has been developed between the university and the two middle schools. This intervention program has continued for 3 years in one of the middle schools, which suggests the staff at this school has an overall positive perception of this intervention. Further, due to the staffing of this intervention with undergraduate students, this intervention fulfilled undergraduate course requirements and experiences. The TIPPS program has contributed to the 
recruitment and training of future school psychologists. All of the graduating undergraduate researchers in the 2019-20 school year went onto school psychology graduate programs.

\section{Limitations}

There were only 51 participants in the study, and a larger sample would have led to higher power and more generalizable results. After random assignment, students were asked to obtain parental permission to be in the study, therefore, gender was not equal among randomly assigned groups. It is possible that the randomization worked, but the gender imbalance was an artifact of which families in each condition consented to the study. There were more females than males in the control group; Male $(\mathrm{N}=5)$ and Female $(\mathrm{N}=18)$. Further, six of the participants $(\sim 11 \%)$ did not complete the CPSS, US Dept of Education School Climate Scale, the ERQ, CMQ, and the LBS, in the fall. Mean substitution was used to substitute this data. Mean substitution was not used for the missing data for the Math and Reading MAP scores.

Due to recruitment and school availability, the TIPPS intervention started later in the fall than originally planned. Therefore, time in the fall only allowed for completion of 9 TIPPS lessons, instead of 14. Lessons were carefully chosen to meet curriculum goals, but some of the main ideas of the intervention may have been limited due to the loss of five lessons.

Pre and post-test measures appeared to be cumbersome to some students. Students expressed concern about the number of items they were asked to answer. It is of concern that students may have experienced test fatigue while completing pre and post-test measures.

In the current evaluation of the intervention, researchers used behavior referrals to indicate behavior change. Research suggests that although this measures a change in referrals, this does not specifically measure behavior change as a result of the intervention (Hoyle, 
Marshall, \& Yell, 2011). Further, research suggests that behavior referrals are not sensitive to change and are susceptible to biases (Rodriguez, Loman, Borgmeir, 2016).

The internal consistency was another concern across the scales. The following scales and subscales had unacceptable internal consistency: the expressive suppression $(\alpha=.353)$ subscale, from the Emotion Regulation questionnaire; the Understand Context $(\alpha=.467)$ and Apply Approach $(\alpha=.469)$ subscales, from the Conflict Management Questionnaire, and the Learning Behaviors $(\alpha=.533)$ scale. Part B of the CPSS $(\alpha=.658)$ has questionable internal consistency. Further, the Learning Behaviors Scale was curriculum-based, instead of research based. The scale was created before losing 5 of the lessons, so the goals of the curriculum this measure was based on may have been lost in this change.

Lastly, the Coronavirus disease halted the administration of TIPPS for the control group in the spring. Initially, the plan was to provide the control group with the intervention because of our ethical responsibility. Despite this, The TIPPS team created a TIPPS at home packet to continue to provide services in an alternative format. Six lessons were delivered in person, and three lessons were delivered via the take-home packets. The TIPPS team created two versions of the take home packets. One version was a take home packet for students to fill out on their own and the second version was a take home packet for students to fill out with their families with ideas to facilitate family discussion. The school counselors decided which students were sent the individual packets and which were sent the family packets. A post-test was not administered. The Coronavirus disease also halted the collection of parent permission and child assent forms for participation in this dissertation project. 


\section{Future Directions}

\section{Research}

Future research should continue to investigate the effectiveness of the Trauma-Informed Program for Promoting Success. Due to the intervention's focus on peer relationships and peer victimization, it would be beneficial for students to be recruited through a bullying screener, such as Student Survey of Bullying Behaviors - Revised, $2^{\text {nd }}$ Edition (SSBB-R2; Varjas, Henrich, \& Meyers, 2008). It would also be beneficial for a bullying or peer victimization measure to be used in monitoring the effectiveness of the intervention.

Further related to assessment measures, future research should measure the effectiveness of the program through a coping skills assessment because many of the skills taught in the intervention relate to coping with stressful situations. An idea for future coping measure is The Kids Coping Scale (Maybery et al., 2009). This scale measure stress and coping in children and adolescents. This measure specifically targets problem-focused coping, emotion-focused coping, and seeking social support. The TIPPS intervention focuses on building problem-solving skills, emotion regulation strategies, and building social support, so this coping skills scale would help to identify effectiveness of the intervention.

Future evaluations of this intervention should consider using other measures of behavior change across time, due to the evidence that behavior referrals are not effective measures of behavior change over time (Rodriguez et al., 2016; Hoyle et al., 2011).

Inclusion of a research-based learning behaviors measure might also be helpful. Research indicates that self-report of one's learning behaviors is not always accurate. Students who are lower performers in school are less accurate in self-report of learning behaviors than higher performers (Rosen, Porter, Rodgers, 2017). The curriculum-based learning behaviors scale 
measured study skills and test anxiety. Therefore, in evaluating the TIPPS intervention, it may be more effective to specifically target test anxiety for a self-report measure, and ask teachers to rate the students' study skills.

Short, weekly surveys were conducted at the end of each lesson to evaluate students' weekly progress. These had different questions each week. In the future, these weekly evaluation forms should have the same questions each week to make analyzing and comparing these evaluations more easily understandable.

Test fatigue was evident during the pre- and post-test data collection times. Therefore, future researchers may want to consider administering the scales over an I-pad or computer to make answering the questions easier and more enjoyable for students. Limiting the number of questions per scale would also be beneficial.

It would be beneficial to collect parent permission and child assent to participate in the research at the same time as collecting parental consent to participate in the intervention. Further, random assignment of participants should be done after matching on pretest scores and demographics to make sure that the groups are equivalent on these variables. Related to random assignment, it could be beneficial to randomly assign by gender so that there are not any significant gender differences between groups.

Further related to the screening and recruitment process, it is essential to have a way to identify students who would meet the requirements for this tier 2 intervention, and those who need more supports and would benefit from an individualized, tier 3, intervention. The screener identified all students' who scored at or above a cutoff point and these students were referred to TIPPS. Those in the TIPPS intervention can be receiving Tier 3 supports at the same time. Data should be collected on the number of students' who are also receiving Tier 3 intervention 
supports. During the implementation of the TIPPS intervention, research team members had to refer students to talk with their counselors. Therefore, it would be beneficial for the researchers to be effectively trained to identify students who need more supports than the intervention can provide them with and to help them find additional supports. For example, the TIPPS intervention facilitates conversations around stressors and coping strategies; during intervention implementation students may report unhealthy coping strategies, such as imminent self-harming behaviors. This is beyond the scope of the intervention and should be addressed through Tier 3 interventions.

It would be beneficial to conduct a mixed-methods study to evaluate the effectiveness of this intervention. Qualitative interviews or focus groups could be conducted. It is hypothesized that students would report feeling a sense of community in TIPPS, making friends, having a safe space to talk, and having their emotions validated. Further, qualitative interviews could be conducted post-intervention with teachers, school counselors, and parents, to gain insight into their perspectives of the effectiveness of the intervention. Follow up interviews could also be conducted with the students a year later to determine their current perceptions of the TIPPS program and to track if they are still using the strategies they learned during the intervention.

Lastly, during the Fall 2019 implementation, some lessons were dropped due to the time restraint. It is suggested to include these lessons to future intervention implementation to evaluate the effectiveness of these additional lessons. The lessons that were not included in this implementation of TIPPS are: Test Anxiety: Stop, Drop, and Roll; Study Skills; SelfMaintenance, Self-Development, Fun; and Positive Space/Safe Space/Climate (Bystander), as well as the introduction lesson and the closing review lesson. 


\section{Practice}

Future ideas of the implementation of the Trauma-Informed Program for Promoting

Success will be discussed. Due to the intervention's focus on providing services for students who have experienced peer victimization, lessons targeting cyberbullying and online safety should be created. Further, the original bullying lesson should be extended into two lessons to ensure that there is ample time for the role-playing scenarios. The current study included a lesson titled Empathy and Peer-Victimization, but due to the interventions focus on peer relationships and peer victimization, additional time should be spent focusing on this topic.

It could be beneficial for a staff member from the school to be a group leader of TIPPS. The students would then have someone from TIPPS at the school at all times. This could be the school counselor, social worker, or psychologist. If this is not feasible, then it is recommended that group leaders create a strong working relationship with school personnel to help facilitate bonds between students and faculty members at the school who are always available for them to talk with. Student connectedness to staff serves as a protective factor for students who experience bullying at school (O’Brennan, Waasdorp, \& Bradshaw, 2014).

A training for teachers should be implemented so that teachers know what skills are being taught in TIPPS. This would help teachers prompt learned problem-solving skills and coping mechanisms throughout the school day. This training could be a short in-person training, or even simply a hand-out for teachers. The goal is to facilitate teacher involvement in the socialemotional learning process. Research suggests that training for teachers regarding peervictimization intervention and prevention programs are associated with their comfort in talking with students and intervening in instances of peer-victimization (O'Brennan et al., 2014). 
Lastly, if possible, more communication with parents might be beneficial. Inclusion of parent engagement in trauma-informed interventions is effective as long as the parent is not the perpetrator (Black, Woodworth, Tremblay, \& Carpenter, 2012). Therefore, since TIPPS is designed for students who are at risk for peer victimization, inclusion of the parent in this intervention could be effective. This could include parent training and/or a parent weekly newsletter. It is possible that home-school lessons could be created for students to discuss topics learned in TIPPS at home. 


\section{REFERENCES}

American Psychological Association. (2013). Recovering emotionally from disaster. Retrieved from https://www.apa.org/helpcenter/recovering-disasters.aspx

American Psychological Association. (2008). Children and trauma update for mental health professionals. Retrieved from https://www.apa.org/pi/families/resources/childrentrauma.pdf.

Anderson, C., \& Borgmeier, C. (2010). Tier II Interventions within the Framework of SchoolWide Positive Behavior Support: Essential Features for Design, Implementation, and Maintenance. Behavior Analysis in Practice, 3(1), 33-45. https://doi.org/10.1007/BF03391756

Arvidson, J., Kinniburgh, K., Howard, K., Spinazzola, J., Strothers, H., Evans, M., ... \& Bath, H. (2008). The three pillars of trauma-informed care. Reclaiming children and youth, 17(3), 17-21.

Black, P. J., Woodworth, M., Tremblay, M., \& Carpenter, T. (2012). A review of traumainformed treatment for adolescents. Canadian Psychology/Psychologie Canadienne, 53(3), 192-203. https://doi-org.libproxy.lib.ilstu.edu/10.1037/a0028441

Blaustein, M. E. (2011). Treatment of complex trauma in young children: Developmental and cultural considerations in application of the ARC intervention model. Journal of Child \& Adolescent Trauma, 4(1), 34-51.

Barr, D. (2018). When trauma hinders learning. Phi Delta Kappan, 99(6), 39-44.

Benight, C. C., \& Bandura, A. (2004). Social cognitive theory of posttraumatic recovery: The role of perceived self-efficacy. Behaviour research and therapy, 42(10), 1129-1148.

Benard, B. (2004). Resiliency: What have we learned? San Francisco: West Ed. 
Blitz, L. \& Lee, Y. (2015). Trauma-informed methods to enhance school-based bullying prevention initiatives: An emerging model. Journal of Aggression, Maltreatment \& Trauma, 24, 20-40. doi: 10.1080/10926771.2015.982238

Bowman-Perrott, L., Davis, H., Vannest, K., Williams, L., Greenwood, C., \& Parker, R. (2013). Academic benefits of peer tutoring: A meta-analytic review of single-case research. School Psychology Review, 42(1), 39.

Brock, S., Nickerson, A., Reeves, M., Conolly, C., Jimerson, S., Pesce, R., \& Lazzaro, B. (2016). School Crisis Prevention and Intervention: The PREPaRE Model. Bethesda, MD: National Association of School Psychologists.

Bryk, A. S., \& Schneider, B. (2003). Trust in schools: A core resource for school reform. Educational leadership, 60(6), 40-45.

Buhrmester, D. (1990). Intimacy of friendship, interpersonal competence, and adjustment during preadolescence and adolescence. Child development, 61(4), 1101-1111.

Carello, J., \& Butler, L. D. (2015). Practicing what we teach: Trauma-informed educational practice. Journal of Teaching in Social Work, 35(3), 262-278.

Cavanaugh, B. (2016). Trauma-informed classrooms and schools. Beyond Behavior, 25(2), 4146.

Cicchetti, D., \& Rogosch, F. A. (2009). Adaptive coping under conditions of extreme stress: Multilevel influences on the determinants of resilience in maltreated children. New Directions for Child \& Adolescent Development, 2009(124), 47-59. https://doiorg.libproxy.lib.ilstu.edu/10.1002/cd.242

Committee for Children. (2008). Second step: Student success through prevention program. Seattle, WA: Author 
Conroy, M. A., Sutherland, K. S., Snyder, A., Al-Hendawi, M., \& Vo, A. (2009). Creating a Positive Classroom Atmosphere: Teachers' Use of Effective Praise and Feedback. Beyond Behavior, 18(2), 18-26.

Copeland, W.E., Keeler, G., Angold, A., Costello, E.J. (2007). Traumatic events and posttraumatic stress in childhood. Archives of General Psychiatry, 64, 577-584. doi:10.1001/archpsyc.64.5.577

Costello, E.J., Erkanli, A., Fairbank, J.A., \& Angold, A. (2002). The prevalence of potentially traumatic events in childhood and adolescence. Journal of Traumatic Stress, 15, 99-112. doi:10.1023/A:1014851823163

Covington, S. S. (2008). Women and addiction: A trauma-informed approach. Journal of psychoactive drugs, 40(sup5), 377-385.

Deblinger, E., Mannarino, A. P., Cohen, J. A., Runyon, M. K., \& Steer, R. A. (2011). Traumafocused cognitive behavioral therapy for children: impact of the trauma narrative and treatment length. Depression \& Anxiety (1091-4269), 28(1), 67-75. https://doiorg.libproxy.lib.ilstu.edu/10.1002/da.20744

Faul, F., Erdfelder, E., Lang, A.-G., \& Buchner, A. (2007). G*Power 3: A flexible statistical power analysis program for the social, behavioral, and biomedical sciences. Behavior Research Methods, 39, 175-191. https://doi.org/10.3758/BF03193146

Foa, E. B., Johnson, K. M., Feeny, N. C., \& Treadwell, K. R. H. (2001). The Child PTSD Symptom Scale: A Preliminary Examination of its Psychometric Properties. Journal of Clinical Child Psychology, 30(3), 376-384. Retrieved from http://libproxy.lib.ilstu.edu/login?url=https://search.ebscohost.com/login.aspx?direct=true $\& \mathrm{db}=\mathrm{a} 9 \mathrm{~h} \& \mathrm{AN}=5209724 \&$ site $=$ eds-live $\&$ scope $=$ site 
Ford, J. D., Elhai, J. D., Connor, D. F., \& Frueh, B. C. (2010). Poly- victimization and risk of posttraumatic, depressive, and substance use disorders and involvement in delinquency in a national sample of adolescents. Journal of Adolescent Health, 46, 545-552.

Gaumer Erickson, A.S. \& Noonan, P.M. (2018). Conflict management formative questionnaire. In The skills that matter: Teaching interpersonal and intrapersonal competencies in any classroom (pp. 183-184). Thousand Oaks, CA: Corwin.

Gaumer Erickson, A.S., Soukup, J.H., Noonan, P.M., * McGurn, L. (2018). Conflict management formative questionnaire technical report. Retrieved from http://www.researchcollaboration.org/uploads/ConflictManagementQuestionnaireInfo.pd f.

Griffin, G., Germain, E. J., \& Wilkerson, R. G. (2012). Using a trauma-informed approach in juvenile justice institutions. Journal of Child \& Adolescent Trauma, 5(3), 271-283.

Gullone, E., \& Taffe, J. (2012). The Emotion Regulation Questionnaire for Children and Adolescents (ERQ-CA): A psychometric evaluation. Psychological assessment, 24(2), 409.

Harrison, P. L., \& Thomas, A. (Eds.). (2014). Best practices in school psychology. National Association of School Psychologists.

Hoyle, C. G., Marshall, K. J., \& Yell, M. L. (2011). Positive Behavior Supports: Tier 2 Interventions in Middle Schools. Preventing School Failure, 55(3), 164-170. https://doiorg.libproxy.lib.ilstu.edu/10.1080/1045988X.2010.503975

Kellam, S. G., Mackenzie, A. C. L., Brown, C. H., Poduska, J. M., Wang, W., Petras, H., \& Wilcox, H. C. (2011). The Good Behavior Game and the Future of Prevention and Treatment. Addiction Science \& Clinical Practice, 6(1), 73-84. 
Klem, A. M., \& Connell, J. P. (2004). Relationships matter: Linking teacher support to student engagement and achievement. Journal of school health, 74(7), 262-273.

Maybery, D., Steer, S., Reupert, A., \& Goodyear, M. (2009). The kids coping scale. Stress \& Health: Journal of the International Society for the Investigation of Stress, 25(1), 31-40. https://doi-org.libproxy.lib.ilstu.edu/10.1002/smi.1228

Macklem, G. L. (2010). Evidence-based school mental health services: Affect education, emotion regulation training, and cognitive behavioral therapy. Springer Science \& Business Media.

Meyer, R. Gold, J., Beas, V., Young, C., \& Kassam-Adams, N. (2015). Psychometric Evaluation of the Child PTSD Symptom Scale in Spanish and English. Child Psychiatry \& Human Development, 46(3), 438-444. https://doi-org.libproxy.lib.ilstu.edu/10.1007/s10578-0140482-2

Nastasi, B. K., Moore, R. B. and Varjas, K. M. (2004). School-based mental health services: Creating comprehensive and culturally specific programs, Washington, DC: American Psychological Association.

National Center for Education Statistics. School climate survey. Washington DC; US Department of Education. Retrieved from: https://safesupportivelearning.ed.gov/sites/default/files/EDSCLS_Questionnaires_112017 .$p d f$

National Child Traumatic Stress Network. (2008). Child trauma toolkit for educators. Retrieved from: https://www.nctsn.org/sites/default/files/resources//child_trauma_toolkit_educators.pdf. 
National Child Traumatic Stress Network. (2012). CBITS: Cognitive Behavioral Intervention for Trauma in Schools. Retrieved from: https://www.nctsn.org/sites/default/files/interventions/cbits_fact_sheet.pdf.

National Child Traumatic Stress Network. (2017). Trauma-informed schools for children in K12: A system framework. Retrieved from https://www.nctsn.org/sites/default/files/resources/factsheet/trauma_informed_schools_fo r_children_in_k-12_a_systems_framework.pdf.

Nixon, C. L. (2014). Current perspectives: the impact of cyberbullying on adolescent health. Adolescent health, medicine and therapeutics, 5, 143.

O’Brennan, L. M., Waasdorp, T. E., \& Bradshaw, C. P. (2014). Strengthening bullying prevention through school staff connectedness. Journal of Educational Psychology, 106(3), 870-880. https://doi-org.libproxy.lib.ilstu.edu/10.1037/a0035957

Odgers, C. L., \& Jaffee, S. R. (2013). Routine versus catastrophic influences on the developing child. Annual review of public health, 34, 29-48.

Overstreet, S., \& Chafouleas, S. M. (2016). Trauma-informed schools: Introduction to the special issue.

Padesky, C. A., \& Mooney, K. A. (2012). Strengths-based cognitive-behavioural therapy: A four-step model to build resilience. Clinical Psychology \& Psychotherapy, 19(4), 283290.

Parris, L. \& Foley, J. (2018, February). Integrating Trauma-Informed Supports in Schools: TIPPS for Practice. Mini-skills presented at the annual National Association of School Psychologists conference, Chicago, IL. 
Parris, L., Varjas, K., Meyers, J., \& Cutts, H. (2012). High school students’ perceptions of coping with cyberbullying. Youth \& Society, 44(2), 284-306.

Perfect, M. M., Turley, M. R., Carlson, J. S., Yohanna, J., \& Saint Gilles, M. P. (2016). Schoolrelated outcomes of traumatic event exposure and traumatic stress symptoms in students: A systematic review of research from 1990 to 2015. School Mental Health, 8(1), 7-43.

Perry, B. D. (2009). Examining child maltreatment through a neurodevelopmental lens: Clinical applications of the neurosequential model of therapeutics. Journal of Loss and Trauma, $14(4), 240-255$.

Perry, B. D., Pollard, R. A., Blakley, T. L., Baker, W. L., \& Vigilante, D. (1995). Childhood trauma, the neurobiology of adaptation, and "use-dependent" development of the brain: How "states" become "traits". Infant mental health journal, 16(4), 271-291.

RB-Banks, Y., \& Meyer, J. (2017). Childhood Trauma in Today's Urban Classroom: Moving Beyond the Therapist's Office. Educational Foundations, 30.

Rodriguez, B. J., Loman, S. L., \& Borgmeier, C. (2016). Tier 2 Interventions in Positive Behavior Support: A Survey of School Implementation. Preventing School Failure, 60(2), 94-105. https://doi-org.libproxy.lib.ilstu.edu/10.1080/1045988X.2015.1025354

Rossen, E. \& Hull, R. (2012). Supporting and Education Traumatized Students: A Guide for School-Based Professionals. New York: NY: Oxford University Press.

Rosen, J., Porter, S., \& Rogers, J. (2017). Understanding Student Self-Reports of Academic Performance and Course-Taking Behavior. AERA Open, 3(2), 233285841771142-. https://doi.org/10.1177/2332858417711427 
Salmivalli, C. (2014). Participant Roles in Bullying: How Can Peer Bystanders Be Utilized in Interventions? Theory Into Practice, 53(4), 286-292. https://doiorg.libproxy.lib.ilstu.edu/10.1080/00405841.2014.947222

Seligman, M. E. (2002). Positive psychology, positive prevention, and positive therapy. Handbook of positive psychology, 2(2002), 3-12.

Shelden, D. L., Angell, M. E., Stoner, J. B., \& Roseland, B. D. (2010). School principals' influence on trust: Perspectives of mothers of children with disabilities. The Journal of Educational Research, 103(3), 159-170.

Sherin, J. \& Nemeroff, C. (2011). Post-traumatic stress disorder: the neurobiological impact of psychological trauma. Dialogues in Clinical Neuroscience, 13(3), 263-278.

Streeck-Fischer, A. \& van der Kolk, B. (2000). Down will come baby, cradle and all: Diagnostic and therapeutic implications of chronic trauma on child development. Australian \& New Zealand Journal of Psychiatry, 34(6), 903-918. doi: 10.1080/000486700265

Steele, W., \& Malchiodi, C. A. (2012). Trauma-informed practices with children and adolescents. Taylor \& Francis.

Substance Abuse and Mental Health Service Administration [SAMHSA]. (2014). SAMHSA's Concept of Trauma and Guidance for a Trauma-Informed Approach. HHS Publication No. (SMA) 14-4884. Rockville, MD: Substance Abuse and Mental Health Services Administration.

Substance Abuse and Mental Health Service Administration [SAMHSA]. (2015). Understanding Child Trauma. HHS Publication No. (SMA) 15-4923. Rockville, MD: Substance Abuse and Mental Health Services Administration. 
Tenenbaum, L. S., Varjas, K., Meyers, J., \& Parris, L. (2011). Coping strategies and perceived effectiveness in fourth through eighth grade victims of bullying. School Psychology International, 32(3), 263-287.

Terrasi, S. \& de Galarce, P. (2017). Trauma and learning in America's classroom. Phi Delta Kappan, 98(6), 35-41.

Tian, D. (2005). The use of psychodrama in dealing with grief and addiction-related loss and trauma. Journal of Group Psychotherapy, Psychodrama and Sociometry, 58(1), 15.

Tigges, B. (2003). Parental Consent and Adolescent Risk Behavior Research. Journal of Nursing Scholarship, 35(3), 283-289. https://doi.org/10.1111/j.1547-5069.2003.00283.x

Tishelman, A. C., Haney, P., O’Brien, J. G., \& Blaustein, M. E. (2010). A framework for schoolbased psychological evaluations: Utilizing a 'trauma lens'. Journal of Child \& Adolescent Trauma, 3(4), 279-302.

Vidourek, R., King, K., \& Merianos, A. (2016). School bullying and student trauma: Fear and avoidance associated with victimization. Journal of Prevention and Intervention in the Community, 44, 121-129. doi: 10.1080/10852352.2016.1132869

Walkley, M., \& Cox, T. L. (2013). Building trauma-informed schools and communities. Children \& Schools, 35(2), 123-126.

Wang, J., Iannotti, R., \& Nansel, T. (2009). School bullying among adolescents in the United States: Physical, verbal, relational, and cyber. Journal of Adolescent Health, 45(4), 368375. doi: 10.1016/j.adohealth.2009.03.021

Westrup, U., \& Planander, A. (2013). Role-play as a pedagogical method to prepare students for practice: The students' voice. Högre utbildning, 3(3), 199-210. 


\section{APPENDIX A: SCREENER}

The Child PTSD Symptom Scale (CPSS)

\section{The Child PTSD Symptom Scale (CPSS) - Part I}

Below is a list of problems that kids sometimes have after experiencing an upsetting event. Read each one carefully and circle the number $(0-3)$ that best describes how often that problem has bothered you IN THE LAST 2 WEEKS.

Please write down your most distressing event:

Length of time since the event:

\begin{tabular}{|c|c|c|c|c|c|c|c|}
\hline \multicolumn{3}{|c|}{0} & \multicolumn{3}{|c|}{1} & 2 & 3 \\
\hline \multicolumn{3}{|c|}{$\begin{array}{l}\text { Not at all or only at } \\
\text { one time }\end{array}$} & \multicolumn{3}{|c|}{$\begin{array}{l}\text { Once a week or less/ } \\
\text { once in a while }\end{array}$} & $\begin{array}{l}2 \text { to } 4 \text { times a week/ } \\
\text { half the time }\end{array}$ & $\begin{array}{c}5 \text { or more times a } \\
\text { week/almost always }\end{array}$ \\
\hline 1. & 0 & 1 & 2 & 3 & $\begin{array}{l}\text { Having } \\
\text { that ca }\end{array}$ & $\begin{array}{l}\text { upsetting thoughts or in } \\
\text { e into your head when }\end{array}$ & $\begin{array}{l}\text { ges about the event } \\
\text { ou didn't want them to }\end{array}$ \\
\hline 2. & 0 & 1 & 2 & 3 & Having & bad dreams or nightma & \\
\hline 3. & 0 & 1 & 2 & 3 & $\begin{array}{l}\text { Acting } \\
\text { (hearin } \\
\text { feeling }\end{array}$ & $\begin{array}{l}\text { r feeling as if the even } \\
\text { something or seeing a } \\
\text { as if I am there again) }\end{array}$ & $\begin{array}{l}\text { Nas happening again } \\
\text { icture about it and }\end{array}$ \\
\hline 4. & 0 & 1 & 2 & 3 & $\begin{array}{l}\text { Feeling } \\
\text { event ( } \\
\text { etc) }\end{array}$ & $\begin{array}{l}\text { upset when you think a } \\
\text { or example, feeling sca }\end{array}$ & $\begin{array}{l}\text { out it or hear about the } \\
\text { d, angry, sad, guilty, }\end{array}$ \\
\hline 5. & 0 & 1 & 2 & 3 & $\begin{array}{l}\text { Having } \\
\text { hear ab } \\
\text { sweat, }\end{array}$ & $\begin{array}{l}\text { feelings in your body } \\
\text { ut the event (for examp } \\
\text { eart beating fast) }\end{array}$ & $\begin{array}{l}\text { en you think about or } \\
\text { e, breaking out into a }\end{array}$ \\
\hline 6. & 0 & 1 & 2 & 3 & $\begin{array}{l}\text { Trying } \\
\text { about } \mathrm{t}\end{array}$ & $\begin{array}{l}\text { ot to think about, talk } \\
\text { e event }\end{array}$ & out, or have feelings \\
\hline 7. & 0 & 1 & 2 & 3 & $\begin{array}{l}\text { Trying } \\
\text { you of }\end{array}$ & $\begin{array}{l}\text { o avoid activities, peop } \\
\text { he traumatic event }\end{array}$ & , or places that remind \\
\hline 8. & 0 & 1 & 2 & 3 & $\begin{array}{l}\text { Not be } \\
\text { upsetti }\end{array}$ & $\begin{array}{l}g \text { able to remember an } \\
\text { g event }\end{array}$ & mportant part of the \\
\hline 9. & 0 & 1 & 2 & 3 & Having & much less interest or do & ig things you used to do \\
\hline 10. & 0 & 1 & 2 & 3 & Not fee & ing close to people arol & d you \\
\hline 11. & 0 & 1 & 2 & 3 & $\begin{array}{l}\text { Not be } \\
\text { being } ~\end{array}$ & $\begin{array}{l}\text { ig able to have strong } \mathrm{f} \\
\text { lable to cry or unable to }\end{array}$ & $\begin{array}{l}\text { lings (for example, } \\
\text { eel happy) }\end{array}$ \\
\hline
\end{tabular}

Page 1 


\begin{tabular}{|c|c|c|c|c|c|c|c|}
\hline 12. & 0 & 1 & 2 & 3 & \multicolumn{3}{|c|}{$\begin{array}{l}\text { Feeling as if your future plans or hopes will not come } \\
\text { true (for example, you will not have a job or getting } \\
\text { married or having kids) }\end{array}$} \\
\hline & \multicolumn{2}{|c|}{0} & & \multicolumn{2}{|c|}{1} & 2 & 3 \\
\hline \multicolumn{3}{|c|}{$\begin{array}{l}\text { Not at all or only at } \\
\text { one time }\end{array}$} & \multicolumn{3}{|c|}{$\begin{array}{l}\text { Once a week or less/ } \\
\text { once in a while }\end{array}$} & $\begin{array}{l}2 \text { to } 4 \text { times a week/ } \\
\text { half the time }\end{array}$ & $\begin{array}{l}5 \text { or more times a } \\
\text { week/almost always }\end{array}$ \\
\hline 13. & 0 & 1 & 2 & 3 & \multicolumn{3}{|c|}{ Having trouble falling or staying asleep } \\
\hline 14. & 0 & 1 & 2 & 3 & \multicolumn{3}{|c|}{ Feeling irritable or having fits of anger } \\
\hline 15. & 0 & 1 & 2 & 3 & \multicolumn{3}{|c|}{$\begin{array}{l}\text { Having trouble concentrating (for example, losing track } \\
\text { of a story on the television, forgetting what you read, not } \\
\text { paying attention in class) }\end{array}$} \\
\hline 6 & 0 & 1 & 2 & 3 & \multicolumn{3}{|c|}{$\begin{array}{l}\text { Being overly careful (for example, checking to see who } \\
\text { is around you and what is around you) }\end{array}$} \\
\hline 17. & 0 & 1 & 2 & 3 & \multicolumn{3}{|c|}{$\begin{array}{l}\text { Being jumpy or easily startled (for example, when } \\
\text { someone walks up behind you) }\end{array}$} \\
\hline
\end{tabular}

\section{The Child PTSD Symptom Scale (CPSS) - Part 2}

Indicate below if the problems you rated in Part 1 have gotten in the way with any of the following areas of your life DURING THE PAST 2 WEEKS.

$\begin{array}{lccl} & \text { Yes } & \text { No } & \\ \text { 18. } & \text { Y } & \text { N } & \text { Doing your prayers } \\ \text { 19. } & \text { Y } & \text { N } & \text { Chores and duties at home } \\ \text { 20. } & \text { Y } & \text { N } & \text { Relationships with friends } \\ \text { 21. } & \text { Y } & \text { N } & \text { Fun and hobby activities } \\ \text { 22. } & \text { Y } & \text { N } & \text { Schoolwork } \\ \text { 23. } & \text { Y } & \text { N } & \text { Relationships with your family } \\ \text { 24. } & \text { Y } & \text { N } & \text { General happiness with your life }\end{array}$




\section{APPENDIX B: SCHOOL CLIMATE SCALE \\ US Department of Education School Climate Scale \\ Other Research-Related Questionnaires (PRE, PLN, PP, ES, SMF) \\ School Climate (PRE, PLN, PP, ES, SMF)}

16. My teachers make me feel good about myself.

$\square$ Strongly Agree

Agree

Disagree

$\square$ Strongly Disagree

17. Students respect one another.

Strongly Agree

$\square$ Agree

Disagree

$\square$ Strongly Disagree

18. Students like one another.

$\square$ Strongly Agree

$\square$ Agree

$\square$ Disagree

$\square$ Strongly Disagree

19. If I am absent, there is a teacher or some other adult at school that will notice my absence. 
$\square$ Strongly Agree

Agree

$\square$ Disagree

$\square$ Strongly Disagree

20. I regularly attend school-sponsored events, such as school dances, sporting events, student performances, or other school activities.

$\square$ Strongly Agree

$\square$ Agree

$\square$ Disagree

$\square$ Strongly Disagree

26. Students at this school get along well with each other.

$\square$ Strongly Agree

$\square$ Agree

$\square$ Disagree

$\square$ Strongly Disagree

27. At this school, students talk about the importance of understanding their own feelings and the feelings of others.

Strongly Agree

$\square$ Agree

$\square$ Disagree 


\section{$\square$ Strongly Disagree}

28. At this school, students work on listening to others to understand what they are trying to say.

Strongly Agree

Agree

Disagree

Strongly Disagree

29. I am happy to be at this school.

$\square$ Strongly Agree

$\square$ Agree

$\square$ Disagree

$\square$ Strongly Disagree

30. I feel like I am part of this school.

$\square$ Strongly Agree

$\square$ Agree

$\square$ Disagree

$\square$ Strongly Disagree

31. I feel socially accepted.

$\square$ Strongly Agree

Agree 
Disagree

Strongly Disagree

32. I feel safe at this school.

[Not included in scale]

Strongly Agree

Agree

Disagree

Strongly Disagree

\section{Bullying and Cyberbullying}

This question is about bullying. Bullying happens when one or more students tease, threaten, spread rumors about, hit, shove or hurt another student. It is not bullying when students of about the same strength or power argue or fight or tease each other in a friendly way. Bullies are usually stronger, or have more friends or more money, or some other power over the student being bullied. Usually, bullying happens over and over, or the student being bullied thinks it might happen over and over.

44. Students at this school are often bullied.

[Item is negatively valenced.]

Strongly Agree

Agree

Disagree 


\section{Strongly Disagree}

45. Students at this school try to stop bullying.

[Not included in scale]

Strongly Agree

$\square$ Agree

Disagree

$\square$ Strongly Disagree

This question is about cyberbullying. Cyberbullying is bullying that takes place using electronic technology. Examples of cyberbullying include mean text messages or emails, rumors sent by email or posted on social networking sites, and embarrassing pictures, videos, websites, or fake profiles.

46. Students often spread mean rumors or lies about others at this school on the internet (i.e., Facebook $^{\mathrm{TM}}$, email, and instant message).

[Item is negatively valenced.]

Strongly Agree

$\square$ Agree

$\square$ Disagree

Strongly Disagree 


\section{APPENDIX C: EMOTION REGULATION SCALE}

Emotion Regulation Questionnaire for Children and Adolescents

\section{1- Strongly Disagree, 2- Disagree, 3- Half and half, 4- Agree, 5- Strongly Agree \\ *Circle the answer that best fits you}

\begin{tabular}{|c|c|c|c|c|c|c|}
\hline & $\begin{array}{l}\text { When I want to } \\
\text { feel happier, I } \\
\text { think about } \\
\text { something } \\
\text { different. }\end{array}$ & $\begin{array}{c}\text { Strongly Disagree } \\
1\end{array}$ & $\begin{array}{c}\text { Disagree } \\
2\end{array}$ & $\begin{array}{c}\text { Half and half } \\
3\end{array}$ & $\begin{array}{c}\text { Agree } \\
4\end{array}$ & $\begin{array}{c}\text { Strongly Agree } \\
5\end{array}$ \\
\hline 2. & $\begin{array}{l}\text { I keep my } \\
\text { feelings to } \\
\text { myself. }\end{array}$ & $\begin{array}{c}\text { Strongly Disagree } \\
1\end{array}$ & $\begin{array}{c}\text { Disagree } \\
2\end{array}$ & $\begin{array}{c}\text { Half and half } \\
3\end{array}$ & $\begin{array}{c}\text { Agree } \\
4\end{array}$ & $\begin{array}{c}\text { Strongly Agree } \\
5\end{array}$ \\
\hline 3. & $\begin{array}{l}\text { When I want to } \\
\text { feel less bad } \\
\text { (e.g. sad, angry } \\
\text { or worried), I } \\
\text { think about } \\
\text { something } \\
\text { different. }\end{array}$ & $\begin{array}{c}\text { Strongly Disagree } \\
1\end{array}$ & $\begin{array}{c}\text { Disagree } \\
2\end{array}$ & $\begin{array}{c}\text { Half and half } \\
3\end{array}$ & $\begin{array}{c}\text { Agree } \\
4\end{array}$ & $\begin{array}{c}\text { Strongly Agree } \\
5\end{array}$ \\
\hline 4. & $\begin{array}{l}\text { When I am } \\
\text { feeling happy, I } \\
\text { am careful not to } \\
\text { show it. }\end{array}$ & $\begin{array}{c}\text { Strongly Disagree } \\
1\end{array}$ & $\begin{array}{c}\text { Disagree } \\
2\end{array}$ & $\begin{array}{c}\text { Half and half } \\
3\end{array}$ & $\begin{array}{c}\text { Agree } \\
4\end{array}$ & $\begin{array}{l}\text { Strongly Agree } \\
5\end{array}$ \\
\hline 5. & $\begin{array}{l}\text { When I'm } \\
\text { worried about } \\
\text { something, I } \\
\text { make myself } \\
\text { think about it in } \\
\text { a way that helps } \\
\text { me feel better. }\end{array}$ & $\begin{array}{c}\text { Strongly Disagree } \\
1\end{array}$ & $\begin{array}{c}\text { Disagree } \\
2\end{array}$ & $\begin{array}{c}\text { Half and half } \\
3\end{array}$ & $\begin{array}{c}\text { Agree } \\
4\end{array}$ & $\begin{array}{c}\text { Strongly Agree } \\
5\end{array}$ \\
\hline 6. & $\begin{array}{l}\text { I control my } \\
\text { feelings by not } \\
\text { showing them }\end{array}$ & $\begin{array}{c}\text { Strongly Disagree } \\
1\end{array}$ & $\begin{array}{c}\text { Disagree } \\
2\end{array}$ & $\begin{array}{c}\text { Half and half } \\
3\end{array}$ & $\begin{array}{c}\text { Agree } \\
4\end{array}$ & $\begin{array}{c}\text { Strongly Agree } \\
5\end{array}$ \\
\hline 7. & $\begin{array}{l}\text { When I want to } \\
\text { feel happier } \\
\text { about something, } \\
\text { I change the way } \\
\text { I'm thinking } \\
\text { about it. }\end{array}$ & $\begin{array}{c}\text { Strongly Disagree } \\
1\end{array}$ & $\begin{array}{c}\text { Disagree } \\
2\end{array}$ & $\begin{array}{c}\text { Half and half } \\
3\end{array}$ & $\begin{array}{c}\text { Agree } \\
4\end{array}$ & $\begin{array}{c}\text { Strongly Agree } \\
5\end{array}$ \\
\hline 8. & $\begin{array}{l}\text { I control my } \\
\text { feelings about } \\
\text { things by }\end{array}$ & $\begin{array}{c}\text { Strongly Disagree } \\
1\end{array}$ & $\begin{array}{c}\text { Disagree } \\
2\end{array}$ & $\begin{array}{c}\text { Half and half } \\
3\end{array}$ & $\begin{array}{c}\text { Agree } \\
4\end{array}$ & $\begin{array}{c}\text { Strongly Agree } \\
5\end{array}$ \\
\hline
\end{tabular}




\begin{tabular}{|c|c|c|c|c|c|c|}
\hline & $\begin{array}{l}\text { changing the } \\
\text { way I think } \\
\text { about them. }\end{array}$ & & & & & \\
\hline 9. & $\begin{array}{l}\text { When I'm } \\
\text { feeling bad (e.g. } \\
\text { sad, angry, or } \\
\text { worried), I'm } \\
\text { careful not to } \\
\text { show it. }\end{array}$ & $\begin{array}{c}\text { Strongly Disagree } \\
1\end{array}$ & $\begin{array}{l}\text { Disagree } \\
2\end{array}$ & $\begin{array}{c}\text { Half and half } \\
3\end{array}$ & $\underset{4}{\text { Agree }}$ & $\begin{array}{c}\text { Strongly Agree } \\
5\end{array}$ \\
\hline & $\begin{array}{l}\text { When I want to } \\
\text { feel less bad } \\
\text { (e.g. sad, angry, } \\
\text { or worried) } \\
\text { about something, } \\
\text { I change the way } \\
\text { I'm thinking } \\
\text { about it. }\end{array}$ & $\begin{array}{c}\text { Strongly Disagree } \\
1\end{array}$ & $\begin{array}{c}\text { Disagree } \\
2\end{array}$ & $\begin{array}{c}\text { Half and half } \\
3\end{array}$ & $\begin{array}{c}\text { Agree } \\
4\end{array}$ & $\begin{array}{c}\text { Strongly Agree } \\
5\end{array}$ \\
\hline
\end{tabular}




\section{APPENDIX D: LEARNING BEHAVIORS SCALE}

Learning Behaviors Scale

1- Strongly Disagree, 2- Disagree, 3- Neutral, 4- Agree, 5- Strongly Agree

*Circle the answer that best fits you

\begin{tabular}{|c|c|c|c|c|c|c|}
\hline & $\begin{array}{l}\text { I know how to calm } \\
\text { myself down when I } \\
\text { am at school. }\end{array}$ & $\begin{array}{c}\text { Strongly Disagree } \\
1\end{array}$ & $\begin{array}{c}\text { Disagree } \\
2\end{array}$ & $\begin{array}{c}\text { Neutral } \\
3\end{array}$ & $\begin{array}{c}\text { Agree } \\
4\end{array}$ & $\begin{array}{c}\text { Strongly Agree } \\
5\end{array}$ \\
\hline 2. & $\begin{array}{l}\text { Being stressed about } \\
\text { schoolwork is always } \\
\text { bad. }\end{array}$ & $\begin{array}{c}\text { Strongly Disagree } \\
1\end{array}$ & $\begin{array}{c}\text { Disagree } \\
2\end{array}$ & $\begin{array}{c}\text { Neutral } \\
3\end{array}$ & $\begin{array}{c}\text { Agree } \\
4\end{array}$ & $\begin{array}{c}\text { Strongly Agree } \\
5\end{array}$ \\
\hline 3. & $\begin{array}{l}\text { There are strategies I } \\
\text { can use when I } \\
\text { become overwhelmed } \\
\text { with my homework. }\end{array}$ & $\begin{array}{c}\text { Strongly Disagree } \\
1\end{array}$ & $\begin{array}{c}\text { Disagree } \\
2\end{array}$ & $\begin{array}{c}\text { Neutral } \\
3\end{array}$ & $\begin{array}{c}\text { Agree } \\
4\end{array}$ & $\begin{array}{c}\text { Strongly Agree } \\
5\end{array}$ \\
\hline 4. & $\begin{array}{l}\text { I have difficulty } \\
\text { managing my time. }\end{array}$ & $\begin{array}{c}\text { Strongly Disagree } \\
1\end{array}$ & $\begin{array}{c}\text { Disagree } \\
2\end{array}$ & $\begin{array}{c}\text { Neutral } \\
3\end{array}$ & $\begin{array}{c}\text { Agree } \\
4\end{array}$ & $\begin{array}{c}\text { Strongly Agree } \\
5\end{array}$ \\
\hline 5. & $\begin{array}{l}\text { I am confident in my } \\
\text { ability to take notes in } \\
\text { class. }\end{array}$ & $\begin{array}{c}\text { Strongly Disagree } \\
1\end{array}$ & $\begin{array}{c}\text { Disagree } \\
2\end{array}$ & $\begin{array}{c}\text { Neutral } \\
3\end{array}$ & $\begin{array}{c}\text { Agree } \\
4\end{array}$ & $\begin{array}{c}\text { Strongly Agree } \\
5\end{array}$ \\
\hline 6. & $\begin{array}{l}\text { I don't know how to } \\
\text { organize my } \\
\text { schoolwork. }\end{array}$ & $\begin{array}{c}\text { Strongly Disagree } \\
1\end{array}$ & $\begin{array}{c}\text { Disagree } \\
2\end{array}$ & $\begin{array}{c}\text { Neutral } \\
3\end{array}$ & $\begin{array}{c}\text { Agree } \\
4\end{array}$ & $\begin{array}{c}\text { Strongly Agree } \\
5\end{array}$ \\
\hline 7. & $\begin{array}{l}\text { Taking a break to calm } \\
\text { down at my desk in } \\
\text { the middle of a test is } \\
\text { okay. }\end{array}$ & $\begin{array}{c}\text { Strongly Disagree } \\
1\end{array}$ & $\begin{array}{c}\text { Disagree } \\
2\end{array}$ & $\begin{array}{c}\text { Neutral } \\
3\end{array}$ & $\begin{array}{c}\text { Agree } \\
4\end{array}$ & $\begin{array}{c}\text { Strongly Agree } \\
5\end{array}$ \\
\hline 8. & $\begin{array}{l}\text { I have difficulty } \\
\text { managing my stress } \\
\text { before a test. }\end{array}$ & $\begin{array}{c}\text { Strongly Disagree } \\
1\end{array}$ & $\begin{array}{c}\text { Disagree } \\
2\end{array}$ & $\begin{array}{c}\text { Neutral } \\
3\end{array}$ & $\begin{array}{l}\text { Agree } \\
4\end{array}$ & $\begin{array}{c}\text { Strongly Agree } \\
5\end{array}$ \\
\hline
\end{tabular}




\begin{tabular}{|c|c|c|c|c|c|}
\hline $\begin{array}{l}\text { 9. If I get stressed while } \\
\text { taking a test, I know } \\
\text { how to relax myself. }\end{array}$ & $\begin{array}{c}\text { Strongly Disagree } \\
1\end{array}$ & $\begin{array}{c}\text { Disagree } \\
2\end{array}$ & $\begin{array}{c}\text { Neutral } \\
3\end{array}$ & $\begin{array}{c}\text { Agree } \\
4\end{array}$ & $\underset{5}{\text { Strongly Agree }}$ \\
\hline $\begin{array}{l}\text { 10. I will become stressed } \\
\text { about schoolwork and } \\
\text { that is okay. }\end{array}$ & $\begin{array}{c}\text { Strongly Disagree } \\
1\end{array}$ & $\begin{array}{c}\text { Disagree } \\
2\end{array}$ & $\begin{array}{c}\text { Neutral } \\
3\end{array}$ & $\begin{array}{c}\text { Agree } \\
4\end{array}$ & $\underset{5}{\text { Strongly Agree }}$ \\
\hline
\end{tabular}




\section{APPENDIX E: FRIENDSHIP SCALE}

\section{Conflict Management Questionnaire}

Please CHECK ONE response that best describes you. Be honest, since the information will be used to help you in school and also help you become more prepared for college and careers. There are no right or wrong answers!

Student ID

\begin{tabular}{|c|c|c|c|c|c|}
\hline & lik & & & & $\begin{array}{c}\text { Very } \\
\text { like me }\end{array}$ \\
\hline & 1 & 2 & 3 & 4 & 5 \\
\hline 1. I can think of several different ways to deal with a disagreement. & $\square$ & $\square$ & $\square$ & $\square$ & $\square$ \\
\hline 2. I have thought about how I normally respond to conflicts. & $\square$ & $\square$ & $\square$ & $\square$ & $\square$ \\
\hline 3. I feel good about how I handle most conflicts or disagreements. & $\square$ & $\square$ & $\square$ & $\square$ & $\square$ \\
\hline 4. The ways I try to resolve conflicts usually work for me. & $\square$ & $\square$ & $\square$ & $\square$ & $\square$ \\
\hline 5. I respond to different disagreements differently. & $\square$ & $\square$ & $\square$ & $\square$ & $\square$ \\
\hline 6. In an argument, I try to understand the other person's point of view. & $\square$ & $\square$ & $\square$ & $\square$ & $\square$ \\
\hline 7. When someone is upset with me, I try to find out why. & $\square$ & $\square$ & $\square$ & $\square$ & $\square$ \\
\hline $\begin{array}{l}\text { 8. If two friends are arguing, I try to understand both sides of the } \\
\text { argument. }\end{array}$ & $\square$ & $\square$ & $\square$ & $\square$ & $\square$ \\
\hline $\begin{array}{l}\text { 9. I try to figure out if someone is arguing just because they're in a bad } \\
\text { mood. }\end{array}$ & $\square$ & $\square$ & $\square$ & $\square$ & $\square$ \\
\hline $\begin{array}{l}\text { 10. Instead of jumping to conclusions, I try to figure out why there's a } \\
\text { disagreement. }\end{array}$ & $\square$ & $\square$ & $\square$ & $\square$ & $\square$ \\
\hline 11. I try to understand if a disagreement is caused by a misunderstanding. & $\square$ & $\square$ & $\square$ & $\square$ & $\square$ \\
\hline 12. When I'm mad at a friend, I avoid talking to him or her. & $\square$ & $\square$ & $\square$ & $\square$ & $\square$ \\
\hline 13. I try to find win-win solutions to disagreements. & $\square$ & $\square$ & $\square$ & $\square$ & $\square$ \\
\hline $\begin{array}{l}\text { 14. When I disagree with someone, I talk about how I feel and listen to } \\
\text { them talk about how they feel. }\end{array}$ & $\square$ & $\square$ & $\square$ & $\square$ & $\square$ \\
\hline $\begin{array}{l}\text { 15. When I'm involved in a disagreement, I stop and think about what I } \\
\text { should say or do. }\end{array}$ & $\square$ & $\square$ & $\square$ & $\square$ & $\square$ \\
\hline 16. During a disagreement I try to find a compromise. & $\square$ & $\square$ & $\square$ & $\square$ & $\square$ \\
\hline 17. If I'm angry with someone, I try to stay calm when we're talking. & $\square$ & $\square$ & $\square$ & $\square$ & $\square$ \\
\hline 18. I try to win every argument, even if I lose friends over it. & $\square$ & $\square$ & $\square$ & $\square$ & $\square$ \\
\hline 19. When I disagree with someone, I try to talk it through with them. & $\square$ & $\square$ & $\square$ & $\square$ & $\square$ \\
\hline $\begin{array}{l}\text { 20. When I disagree with someone, I defend my position but I don't put } \\
\text { the other person down in the process. }\end{array}$ & $\square$ & $\Gamma$ & $\square$ & $\square$ & $\square$ \\
\hline 21. During an argument, I often say things that I later regret. & $\square$ & $\square$ & $\square$ & $\square$ & $\square$ \\
\hline
\end{tabular}

